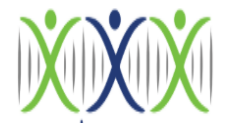

iRASD

Volume 9, Number 3, 2021, Pages 365-385

SCIENCES (P.JSS

Journal Homepage:

https://journals.internationalrasd.org/index.php/pjhss

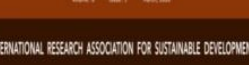

\title{
Nexus between Governance Indicators \& Sustainable Stock Market Development in Pakistan: Evidences from Symmetric and Asymmetric Analysis
}

Kashif Islam ${ }^{1}$, Ahmad Raza Bilal²

${ }^{1}$ Ph.D. Scholar, Department of Business \& Management Sciences, Superior University Lahore, Pakistan. Email: kashifislamroyal@gmail.com

2 Associate Professor, Department of Business \& Management Sciences, Superior University Lahore, Pakistan. Email: arb@superior.edu.pk

\section{ARTICLE INFO}

Article History:

Received:

Revised:

Accepted:

October 16, 2021

December 06, 2021

December 08, 2021

Available Online: December 09, 2021

Keywords:

Governance Indicators

ARDL

NARDL

Asymmetry and SMD

\section{ABSTRACT}

The hidden non-linear association between governance indicators \& stock market development (SMD) of Pakistan has been scrutinized in this study by using two comparative co-integrating techniques known as ARDL (Auto-regressive Distributed Lag) \& NARDL (Nonlinear ARDL). Empirical evidence suggests that misrepresented inferences arise by ignoring hidden non-linearity nexus between the variables. The ARDL results indicate that political stability \& absence of violence/terrorism does not impact directly the SMD of Pakistan. Voice \& accountability positively and significantly impact SMD, but rule of law does not impact SMD of Pakistan directly. The regulatory quality is highly significant and negatively impacts SMD. Contrarily, the NARDL frame indicates significant differences amid coefficients of components of governance index, denoting asymmetric links between variables. The Positive \& Negative sums of partial decompositions of Rule of Law, Regulatory Quality, Political Stability \& Absence of Violence/Terrorism (PS\&AVT), and Voice \& Accountability (V\&A) significantly impact SMD. The impact of partial Negative multipliers of Regulatory Quality, and PS\&AVT has a highly significant and negative impact, while $V \& A$ has a significant and positive impact on SMD. The impact of Positive partial multipliers of all variables is positive and significant except V\&A. The comparative diagnostics extricate precariousness in policy moratorium. This study will add credence to the predictive power of governance indicators towards SMD of Pakistan by incorporating Positive and Negative decomposed multipliers.

(c) 2021 The Authors, Published by iRASD. This is an Open Access Article under the Creative Common Attribution Non-Commercial 4.0

Corresponding Author's Email: kashifislamroyal@gmail.com

\section{Introduction}

The latest theoretical and scientific literature predicts that governance and growth of stock markets are closely associated and follow hand in glove mechanism (Bilan, Vasilyeva, Lyeonov, \& Bagmet, 2019; Ellahi et al., 2021; Yusuf \& Solmaz, 2020). Governance efficiency refers to institutional quality in any frontier economy ${ }^{1}$ like Pakistan is supposed to have a major impact on overall business growth (Al-Gasaymeh, 2020; Wang \& Macy, 2021). Extensive research is undertaken to investigate the impact of various governance indicators like voice and accountability (V\&A), government effectiveness (GE), regulatory quality (RQ), control of corruption (COC), rule of law (ROL), and political stability \& absence of violence/terrorism (PS\&AVT) respectively on the growth, liquidity \& volatility of stock market development of Pakistan (Modugu \& Dempere, 2020). Still, there is no agreement as to whether the hidden link is positive or negative, symmetrical/uni-directional or

\footnotetext{
${ }^{1}$ The term Frontier Economy has been defined "the economy having distinct characteristics/features by the relative scarcities (and high prices) of capital assets like equipment, plant and skilled labor, and by the relative abundance (and low prices) of the natural resources. Due to these factors, the producers or the sellers look to utilize these natural resources instead of skilled labor or capital whenever possible.
} 
asymmetrical/bi-directional between variables (M. A. Khan et al., 2020; Lakshmi, Saha, \& Bhattarai, 2021; Ming \& Jais, 2021; Sheikh, Shah, \& Akbar, 2018; Umar \& Nayan, 2018).

The last two decades indicate that emerging-market economies like Pakistan that have expanded into frontier ${ }^{2}$ economies, the boom in the emerging economies' stock markets mostly attributes towards economic \& financial growth, based upon good governance. The capital market growth (CMG) and boom in all emerging or frontier markets also led to structural changes in developed/advanced economies' financial systems (Bilan et al., 2019; Bogdan \& Lomakovych, 2021). A number of macro-economic variables and guidance metrics have attributed the growth of stock markets (Hannah, 2019; M. A. Khan, Ilyas, \& Hashmi, 2018; Ming \& Jais, 2021; Modugu \& Dempere, 2020).

Many reports have examined the macroeconomic effects on the growth of financial markets in less developed economies like Pakistan (Chaudhry, Faheem, Farooq, \& Ali, 2021; Gulay, 2019). However, studies are still under way by testing the impact of governance indicators on stock market growth (Kwenda \& Chinoda, 2019). There is general agreement that governance indices like (i) voice and accountability (V\&A) (ii) rule of law (ROL) (iii) regulatory quality (RQ) (iv) control on corruption (COC) and ( $v$ ) political stability and absence of violence and terrorism (PS\&AVT) have uni-directional effect on stock market growth (Bilan et al., 2019; M. A. Khan et al., 2020). The studies highlight an important issue as how governance through its components has distinct effects the sustainable performance of stock market of Pakistan. It is also a critical issue as to whether economic or financial growth policies in the emerging countries can be modified and properly implemented through quality governance mechanism (Abduvaliev, 2021; Hussain, Rafique, Khalil, \& Nawaz, 2013; Udoh et al., 2021).

A list of studies shows that governance indicators (GI) have a favorable impact on stock market growth (SMG). Different studies like Boadi and Amegbe (2017) and Choi, Chung, Kim, Kim, and Choi (2020) have shown good governance in the form of a sustainable stock market development and its role in economic \& financial liberalization strategies. In the countries, with extremely weak enforcement of shareholders' rights and corporate level governance can be much more critical at micro-economic level. The same is true for country's dysfunctional justice system. The studies that wet this discussion include Chen, Hongo, Ssali, Nyaranga, and Nderitu (2020) and Reddy (2019). In an old study, Kaufmann, Kraay, and Mastruzzi (2011) stated that governance quality is the only variable that is essential for the growth of stock markets, but it can also jeopardize policy growth strategies, if it is badly tackled. It is also well recognized that quality of governance has significant impact on stock market volatility (SMV). The research work of Lee and Kim (2020) indicates that the indices of governance like (i) control on corruption (ii) regulatory quality \& (iii) protection of ownership rights could build and improve trust in the investment of stocks. The claim that the growth of quality institutions has a major impact on financial markets' development is backed by many research endeavors like (K. Ahmed, Khan, \& Ozturk, 2021; Atiq-ur-Rehman, Ditta, Nawaz, \& Bashir, 2020; Kwenda \& Chinoda, 2019; Nirola \& Sahu, 2019). Extensive analyses indicate that the nexus of growth of stock market is closely linked to the studies on interaction of regulatory system with financial sector. According to Eichler and Plaga (2020) the weaker/underdeveloped financial markets appear to exist in the countries with weaker/lower law enforcement and law structures (Cho, Greenwood-Nimmo, \& Shin, 2021; M. A. Khan et al., 2018; Mehmood, MohdRashid, Aman-Ullah, \& Zi Ong, 2021; Razi, Zahoor, \& Abbas, 2021; Rysin et al., 2021).

To date, there are few quantitative studies in Pakistan that address/handle the impact of governance indicators on SMD by using ARDL \& NARDL in a single study. Most of the studies and dissertations address these policy variables by incorporating uni-directional effect and ignore the bi-directional (joint impact of Positive \& Negative Multipliers). This study is meant to investigate this discussion by comparing the results of ARDL \& NARDL frame by incorporating the impact of selected components of governance indicators. The joint impact of ROL, RQ, PS\&AVT and V\&A on SMD of Pakistan in its true Positive \& Negative partial multipliers

\footnotetext{
2 According to the Morgan Stanley Composite Index (MSCI) report 2021, recently published, Pakistan has been included in the list of "Frontier Market" that was previously classified as an "Emerging Market".
} 
determines the significance of this Study and it constitute the real research gap. This study will provide new insights in policy formulation and implementation.

This paper addresses only selected institutional and governance indicators and ignores a list of related ones: like regulatory/government effectiveness, fiscal and monetary freedom, financial inclusion or liberalization, trade, fiscal and investment policies. The time and cost limitations highlight that in future research studies, these variables must be accommodated. The rest of the paper has been organized as: section 2 will deal with the review of literature. Section 3 will explain the brief comparative analysis of two methodologies and Section 4 will cover results, analysis and discussion. The last section of this paper will provide new insights and suggestions for proposed policy modification.

\section{Literature Review}

As discussed earlier, the focus of this study is to investigate the comparative analysis of asymmetric links between selected governance indicators (rule of law, regulatory quality, voice and accountability and government effectiveness) variables with SMD of Pakistan. The four selected governance indicators have been briefly discussed below: -

\subsection{Rule of Law}

Rule of law has been the first selected component of governance indicator (GI). Luong, Nguyen, and Nguyen (2020) stressed the effect of relevant legislation on stock market growth (SMG) and its implementation. Investors are encouraged to invest with the requisite financial support and well protected investors' rights through courts and business regulations. Though, countries with poor legal regime and affected laws would dissuade borrowers and lenders from financing (Dima, Barna, \& Nachescu, 2018; Uzelac, Davidovic, \& Mijatovic, 2020).

This paper analyzes empirically the effects of regulations on stock market predictions due to the role of regulations in doing business. In the event of well-defined and implemented rules/regulations concerning financial sector growth, issues of asymmetry and poor financial disclosure can be significantly reduced (K. Ahmed et al., 2021; Kaufmann et al., 2011; Shang, Li-Bo, Han-Long, \& Dong-Liang, 2021). However, it is argued that sound and efficient financial market regulations (FMR) are the prerequisites to stock market growth (SMG), but most of the studies do not focus less developed countries with little data availability for the emerging markets like Pakistan (Chiad \& Sahraoui, 2021; M. A. Khan et al., 2018; Shaohua, Yahya, Pham, \& Waqas, 2021; Sheikh et al., 2018; Sohail, Rasul, \& Fatima, 2017).

Bilan et al. (2019) reported that corporate governance is essential to, or can substitute, country-wide judicial/regulatory reforms. This is because countries with poor legal structure often have lower corporate governance and lower equity market growth. This shows that the absence of effective rules and their non-compliance cannot promote financial development. Cross-country research of corporate governance focusses $R O L$ as an essential component of economic and financial development (M. M. Ahmed, 2021; Bogdan \& Lomakovych, 2021; Y. Dang, 2021; Jareño, Escribano, \& Koczar, 2020; M. A. Khan et al., 2020; Phuong, 2020).

\subsection{Regulatory Quality}

There is Regulatory quality, being the second component of Governance. Since, there are no specific predictive regulatory factors for the variability of a stock market (Ming \& Jais, 2021; Umar \& Nayan, 2018). Hence, Manasseh, Mathew, and Ogbuabor (2017) pointed that proper securities legislation enhances financial reporting accuracy, clarity and trust of investors. In the same way, Emara and El Said (2021) stated that in countries with effective regulatory mechanism duly backed by the legal structure, the financial markets are well developed and efficient (Emara \& El Said, 2021; Kamrana, Nawazb, \& Rizwan, 2020; M. A. Khan et al., 2020; Ming \& Jais, 2021; Modugu \& Dempere, 2020; Nguyen, Chaiechi, Eagle, \& Low, 2020; Shang et al., 2021; Zungu \& Grelying, 2021).

Bilan et al. (2019) have reiterated that enhancing regulatory quality will boost interest, confidence $\&$ trust in equity investments. Hence, foreign investors could derive more returns from quality organizations. Kaufmann et al. (2011) echoed the implementation of good quality regulations/rules and re-affirmed that states with weak institutions will lead to immature financial markets with regard to its transparency, investors' security, liquidity and quality regulatory measures (Bilan et al., 2019; de Batz, 2020; Hilliard \& Zhang, 2019; M. A. Khan et al., 2020; Manasseh et al., 2017; Ming \& Jais, 2021). 
Galindo-Manrique, Pérez-Calderón, and Rodríguez-García (2021) reignited the development of financial \& regulatory markets are related to increased volume of transparency of information. The failure to disclose regulatory information about their quality operations will give bad signal to current and prospective investors, hence negative shock to equity market growth (D. Dang, Fang, \& He, 2019; Hannah, 2019; Shaohua et al., 2021). Extensive studies indicate that the role of financial market regulations (FMR) in relation to SMD of Pakistan has been inverse though not highly significant one (Boadi \& Amegbe, 2017). This shows that all government regulators make no strict/stringent attempts to ensure that new rules are complied with and enforced on the equity markets. If government and other related institutions perform its respective jobs effectively, they can promote more productive activity by mitigating market manipulations relating to the capital markets of the developed economies (Abeka, Andoh, Gatsi, \& Kawor, 2021; Islam \& Islam, 2020; Jareño et al., 2020; M. A. Khan et al., 2018; Uzum, Ikpefan, Omankhanlen, Ejemeyovwi, \& EHIKIOYA, 2021).

Sheikh et al. (2018) reiterated that legislation relating to securities encourage capital \& equity market growth in different ways to fuel economic pace by creating new quality productive investment opportunities. Further, stock market system (SMS) is sanitized with stringent equity legislations to handle asymmetric information (Bogdan \& Lomakovych, 2021; Chien et al., 2021; Y. Dang, 2021; Eldomiaty, Al Qassemi, Mabrouk, \& Abdelghany, 2016; Uzelac et al., 2020; Uzum et al., 2021).

\subsection{Voice \& Accountability}

Voice \& accountability ( $\mathrm{Q} \& \mathrm{~A}$ ) have been the third selected component of governance indicators. It plays an important role in every country's capital market stability, volatility, liquidity, growth and performance. Investors' vulnerability for market practices has risen with the persistence of global financial crises (GFC) affecting the leading firms (Boadi \& Amegbe, 2017; Ming \& Jais, 2021; Modugu \& Dempere, 2020). Investors are looking more at the transparency and consistency of equity markets with quality corporate management policies (D. Dang et al., 2019; Sohail et al., 2017). In a financial era of modern times, firms are not operating in a vacuum but are instead influenced by their host ecosystem governance structures that is directly influenced by voice and accountability mechanisms (Kinsella, Mehrbani, Weiser, \& Weiner, 2020; Lakshmi et al., 2021; Modugu \& Dempere, 2020; Montes, Bastos, \& de Oliveira, 2019; Shaohua et al., 2021).

Different reports have investigated the impact of V\&A on stock market growth of grease-induced systemic vulnerability. Rather, it has created the possibility of stock market volatility (SMV) due to investor's risk mitigation mechanism (Luong et al., 2020; Nguyen et al., 2020). In addition, Lee and Chou (2020) extensively examined the link between legal environment, risk mitigation and stock market returns. The results indicate that efficient, transparent and legal system manifested by higher quality legal \& political system, adequate protection of investors by significant increase in the performance of equity market portfolios (Kinsella et al., 2020; Mangal \& Liu, 2020; Noshad, Amjad, Shafiq, \& Gillani, 2019). Similarly, Chizema and Pogrebna (2019) followed by Shaohua et al. (2021) iterated that states with unbiased better transparent \& accountable legal system tend to attract new investors and to retain the old investors to promote stock market development (SMD) and to improve overall financial system of countries of third world (Almaharmeh, Shehadeh, Iskandrani, \& Saleh, 2021; Galindo-Manrique et al., 2021; Ming \& Jais, 2021; Shi, Ahmed, \& Paramati, 2021).

The study of Modugu and Dempere (2020) echoed that favorable association between the quality of institutions and risk-adjusted return on assets of the legal institutions has been investigated. They further extended that lawyer's quality can extend return on equity by reducing firms' expenses amid shareholders and management. Kinsella et al. (2020) recapped that poor accountability will prefer to finance more debt financing than equity financing. Sohail et al. (2017) shows that various businesses in those countries with poor governance indicators prefer to fund more debt financing than equity acquisitions. Since capital markets with a bad governance system have higher agency and transaction costs, while equity offers lesser level of control for investors than debt financing. So, the demand for equity in poorly regulated in financial markets resulting in lower returns on equity (Amjad, Ehsan, Amjad, \& Gillani, 2021; 
Chizema \& Pogrebna, 2019; Diallo, Mendy, \& Burlea-Schiopoiu, 2021; Gulyamov, 2021; Shaohua et al., 2021; Sheikh et al., 2018).

\subsection{Political Stability and Absence of Violence/Terrorism}

Political stability and absence of violence/terrorism is the $4^{\text {th }}$ selected component of governance indicators. Studies have proved that it plays a pivotal role in the development of economic and financial growth of any country (Abdul Rahman \& Saif, 2020; Husnain, Islam, \& Ali, 2020; Ming \& Jais, 2021). Both components: (i) political stability (PS) \& (ii) absence of violence/terrorism (AVT) have positive, significant and major impact on the stock market returns (SMR) and economic development (ED) particularly in Pakistan. Pakistan has been a frequent victim of political instability and terrorism after 09/11/2001 attacks in USA (Abdul Rahman \& Saif, 2020; Emara \& El Said, 2021; Fareed, Meo, Zulfiqar, Shahzad, \& Wang, 2018; Ming \& Jais, 2021). In this paper, the researcher has discussed the distinct impact of political, violence and terrorism events on stock returns of Pakistan that how political news and acts of terrorisms had affected stock market. The research studies during the last two decades indicate that above mentioned factors are the major contributory factors of the variability in stock returns of Pakistan (Abdul Rahman \& Saif, 2020; Haseeb, Wattanapongphasuk, \& Jermsittiparsert, 2019; Husnain et al., 2020; Masood, Javaria, \& Petrenko, 2020; Monsura \& Villaruz, 2021; Uzelac et al., 2020).

There has been a considerable investigation of possible correlational levels of stable political environment and terrorism with the bond or equity market of Pakistan, and still no agreement on the background, methods, methodology and strategies has ever been reached in literature (Ajide, 2019; H. Khan, Khan, \& Zuojun, 2020). Economic growth and political stability are perceived to be directly proportional i.e., if political conditions are stable, then economic growth will boost and vice versa. For example, politically instable governments spend lavishly and indulge in certain social evils like grafting, expropriation, embezzlement of funds, nepotism, favoritism, political victimization and fraudulent activities to pay off illegal rewards/bonuses to their allies and generate illegitimate revenues to handle their opponents and ultimately, they impact economic policy (EP) negatively (Gulyamov, 2021; Lepore, Paolone, \& Cambrea, 2018; Modugu \& Dempere, 2020; Montes et al., 2019).

Numerous empirical studies have found in the literature to investigate the influence of terrorism activities on the stock market around the world. In general, growth of stock market declines from terrorist activities and it makes investors unwilling to retain their business in case of unpredictable future events (Asaad \& Marane, 2020; Masood et al., 2020). Moreover, terrorism events produce extreme level uncertainty and high risk for new investment projects and operational risks for the existing projects that adversely influence financial markets. Hence, ultimate decrease in economic and financial development (Abeka et al., 2021; Bhatti, Chaudhry, \& Bashir, 2021; Boadi \& Amegbe, 2017; Fareed et al., 2018; Mirza, Abbas, \& Nawaz, 2020; Tag, 2021).

\section{Data Collection, Methodological Framework \& Econometric Modelling}

The annual time series data of Pakistan Stock Exchange (PSX) of last twenty-five years (1996-2020) has been used to investigate the impact of selected governance indicators (ROL, $R Q, V \& A, \& P S \& A T V$ ) on SMD of Pakistan. The data of governance indicators has been downloaded from the official web site (info.worldbank.org. /governance/wgi) produced by Daniel Kaufmann, president emeritus NRGI and Aart Kraay. This study uses annual time series data of PSX for twenty-five years (1996-2020). The annual time series data of stock market development (SMD) has been downloaded from the official World Development Data web site (https://databank.worldbank.org/).

\section{Table 1: List of Dependent \& Independent Variables}

\begin{tabular}{llll}
\hline Description of Variables & Variables & Unit of Measurement & Data Sources \\
\hline $\begin{array}{l}\text { Stock Market } \\
\text { Development }\end{array}$ & SMD & $\begin{array}{l}\text { Stock Market Turnover } \\
\text { as \% of Total GDP }\end{array}$ & $\begin{array}{l}\text { World Development Indicators } \\
\text { (WDI, 2020) }\end{array}$ \\
\hline Rule of Law & ROL & 1st Component of Index & World Governance Indicators \\
\hline Regulatory Quality & RQ & 2nd Component of Index & World Governance Indicators \\
\hline Voice \& Accountability & V\&A & $3^{\text {rd }}$ Component of Index & World Governance Indicators \\
\hline $\begin{array}{l}\text { Political Stab. \& Absence } \\
\text { of Violence/Terrorism }\end{array}$ & PS\&AVT & $4^{\text {th }}$ Component of Index & World Governance Indicatorss \\
\hline
\end{tabular}


To measure SMD, stock market turnover (percentage of GDP) has been used as proxy (Ajide, 2019; M. A. Khan et al., 2020). The proxies like (i) total value of shares traded on market, (ii) number of shares traded on market (iii) market capitalization (percentage of GDP) (iv) number of listed companies on per annum basis (v) market capitalization (as US dollar) has been used in a large number of research papers and dissertations. The proxy (stock market turnover as a percentage of GDP) has been finalized with an extensive deliberation by using E-views-10 in order to run the analysis of ARDL \& NARDL framework respectively.

\subsection{Methodological Frame}

At present literature, the linear models completely dominate and consider a symmetric link (uni-directional link) between various components of GI and SMD. The experts have studied linearity but have ignored its non-linearity aspect. To fill this gap with respect to Pakistan, Non-linear auto regressive distributed lag (NARDL ${ }^{3}$ model) has been applied to capture two forms of relationships i.e., unidirectional and bi-directional short-run as well as long-run dynamics at disaggregate levels. NARDL technique has been developed by Shin, Yu \& Greenwood-Nimmo in 2014. NARDL is a new technique for detecting nonlinearities amid Financial \& Economics variables. This methodology can be applied even if variables are integrated at $I(0)$ or $I(1)$. The results of ARDL become invalid when $I(2)$ variable is included in analysis. The results become robust regardless of its nature of sample, and it adjusts lags in its models to deliver unbiased estimates with valid estimated t-statistics' (Chen et al., 2020; Cho et al., 2021; Jareño et al., 2020).

ARDL framework for cointegration, was developed by Pesaran et al. (2001). This is an OLS model that enjoys greater statistical authority compared to classical cointegration techniques called CLRM. It can handle mixed order integration for time series data. But it does not handle Positive and Negative shocks in the variables that occur due to its Positive \& Negative decomposed multipliers to tackle spurious regressions. NARDL is the advanced version of ARDL ${ }^{4}$. It works effectively for small samples (Nkoro \& Uko, 2016). Error Correction Model (ECM) has been used to capture the short-run and long-run dynamics (Ghardallou \& Boudriga, 2014). Further, ARDL \& NARDL with ECM is useful to disentangle 'long-run' links from short-run dynamics. These methods also deal with diagnostics (like endogeneity, serial correlation \& heteroscedasticity) in the time series data. The paper covers the comparison of two econometric techniques (ARDL \& NARDL) to suggest more accurate inferences. This helps to formulate future policy making strategy recommendations in a better way by pointing out unscratched nonlinearities (known asymmetries), that cover Positive \& Negative shocks in the explanatory variables, due to diverse dynamics of ever- changing macro-economic predictors.

\subsection{Econometric Model}

The following equations have been formulated to test the hidden long-run \& short- run uni-directional and bi-directional impact of the selected governance indicators (GI) on Stock Market Development (SMD) of Pakistan.

$$
\begin{gathered}
S M D=\beta \theta+\beta 1(G I)+\mu \\
S M D=\beta 0+\beta 1(R O L)+\beta 2(R Q)+\beta 3(V \& A)+\beta 4(P S \& A T V)+\mu
\end{gathered}
$$

The long run parameters are, namely $\beta 0 \& \beta 1$ for governance indicators index [GI], in equation [1]. In Equation [2], $\beta 1, \beta 2, \beta 3$, and $\beta 4^{5}$ denote $R O L$ for rule of law, $R Q$ for regulatory quality, $V \& A$ for voice and accountability and $4^{\text {th }}$ variable, selected from the Index is PS\&ATV for political stability and absence of violence/terrorism respectively. To cover bi-directional dynamics in the model, the equation (1) has been remodeled by using ECM parameters that has been developed by Smith, Shin, and Pesaran (2001). The proposed equation [04] will be:

$$
\begin{aligned}
& \Delta S M D=\theta+\sum_{k=1}^{p 1} \theta \Delta S M D(\mathrm{t}-\mathrm{k})+\sum_{k=1}^{p 2} \theta \Delta R O L(\mathrm{t}-\mathrm{k})+\sum_{k=1}^{p 1} \theta \Delta R Q u a(\mathrm{t}-\mathrm{k}) \sum_{k=1}^{p 1} \theta \Delta V \& A(\mathrm{t}- \\
& \mathrm{k})+\sum_{k=1}^{p 1} \theta \Delta P S \& A T V(\mathrm{t}-\mathrm{k})+\lambda 1 R O L(\mathrm{t}-1)+\lambda 2 R Q(\mathrm{t}-1)+\lambda 3 V \& A(\mathrm{t}-1)+\lambda 4 P S \& A T V(\mathrm{t}-1)+\mu
\end{aligned}
$$

\footnotetext{
${ }^{3}$ NARDL covers the bi-directional impact between independent and dependent variables

${ }^{4}$ ARDL methodology is an appropriate modification of orders of ARDL frame $(p, q)$, that is necessary to rectify the problem of 'endogenous regressors' \& residual 'serial correlation' simultaneously (Pesaran and Shin, 1999). But, NARDL model decomposes every series into positive and negative values that are not I(1). The degree of persistence will correct any endogeneity, e.g., if the variables are $\mathrm{I}(\mathrm{d})$, the correction is better for the values of ' $\mathrm{d}$ ' closer to1.00.

${ }^{5}$ Beta is a measure of Stock Price Volatility (SPV) w.r.t. overall stock market. Higher Beta means higher potential returns with higher riskier security. If a stock moves less than market, the stock's beta will be less than 1.00
} 
The equation [03] here, is parallel to statistical study conducted by Engle and Granger (1987). The proxy in equation above is a linear form of the under-study variables that shows its lagged values. Further, in equation [3], the long-run coefficients are denoted by $\lambda 1, \lambda 2, \lambda 3$, $\& \lambda 4$ respectively, while short-run coefficients are reflected by $\theta$. The presence of cointegration between GI \& SMD of Pakistan is substantiated by F-Bounds test stats. The test is recommended by Pesaran et al., (2001). The equation [3] assumes symmetrical hidden links amid GI and SMD of Pakistan. The second objective of this research is to test nonlinear/asymmetric impact of selected components of governance index on SMD of Pakistan. Here, non-linear/asymmetric regression shown as:

$$
x_{t}=\delta^{+} y_{t}^{+}+\delta^{-} y_{t}^{-}+\mu_{t} \text {, where } \delta^{+} \text {and } \delta^{-}
$$

This equation links long-run coefficients, here $\mathrm{yt}_{\mathrm{t}}$ shows the vector of explanatory variables that is disintegrated as; The following equations $[4,5,6,7,8,9,10,11]$ show non-linear trend denoted by partial multipliers of hidden Positive and Negative changes in rule of law, regulatory quality, voice $\&$ accountability and the $4^{\text {th }}$ selected component of governance index political stability and absence of violence/terrorism respectively.

$$
\begin{gathered}
\sum_{i=1}^{t} R O L+=\sum_{i=1}^{t} \Delta R O L+=\sum_{i=1}^{t} R O L \max (\Delta R O L i, 0) \\
\sum_{i=1}^{t} R O L-=\sum_{i=1}^{t} \Delta R O L-=\sum_{i=1}^{t} R O L \min (\Delta R O L i, 0) \\
\sum_{i=1}^{t} R Q+=\sum_{i=1}^{t} \Delta R Q=\sum_{i=1}^{t} R Q \max (\Delta R Q i, 0) \\
\sum_{i=1}^{t} R Q-=\sum_{i=1}^{t} \Delta R Q=\sum_{i=1}^{t} R Q \min (\Delta R Q, 0) \\
\sum_{i=1}^{t} V \& A+=\sum_{i=1}^{t} \Delta V \& A \sum_{i=1}^{t} V \& A \max (\Delta V \& A i, 0) \\
\sum_{i=1}^{t} V \& A-=\sum_{i=1}^{t} \Delta V \& A \sum_{i=1}^{t} V \& A \min (\Delta V \& A i, 0) \quad(9) \\
\sum_{i=1}^{t} P S \& A V T+=\sum_{i=1}^{t} \Delta P S \& A V T=\sum_{i=1}^{t} P S \& A V T \max (\Delta P S \& A V T i, 0) \\
\sum_{i=1}^{t} P S \& A V T-=\sum_{i=1}^{t} \Delta P S \& A V T=\sum_{i=1}^{t} P S \& A V T \min (\Delta P S \& A V T i, 0)
\end{gathered}
$$

In order to develop non-linear/asymmetric ARDL framework (called NARDL), here the equations generated above (from Eq.4 to Eq.11) have been put into equation [4] to produce equation [12], that represents desired NARDL equation for the model under-study.

$$
\begin{aligned}
& \left.\Delta S M D=\theta+\sum_{k=1}^{p 1} \theta \Delta S M D(\mathrm{t}-\mathrm{k})+\sum_{k=1}^{p 2} \theta \Delta R O L(\mathrm{t}-\mathrm{k})+\sum_{k=1}^{p 3} \theta \Delta R Q(\mathrm{t}-\mathrm{k})+\sum_{k=1}^{p 4} \theta \Delta V \& A(\mathrm{t}-\mathrm{k})\right)+ \\
& \sum_{k=1}^{p 5} \theta \Delta P S \& A V T(\mathrm{t}-\mathrm{k})+\sum_{k=1}^{p 6} \theta R O L(+)+\sum_{k=1}^{p 7} \theta \mathrm{ROL}(-)+\sum_{k=1}^{p 8} \theta R Q(+)+\sum_{k=1}^{p 9} \theta R Q(-)+ \\
& \sum_{k=1}^{p 10} \theta V \& A(+)+\sum_{k=1}^{p 11} \theta V \& A(-)+\sum_{k=1}^{p 12} \theta P S \& A V T(+)+\sum_{k=1}^{p 13} \theta P S \& A V T(-)+\lambda 1 R O L(\mathrm{t}-1)+\chi 2 \mathrm{R} Q(\mathrm{t}- \\
& 1)+\chi 3 \mathrm{~V} \& A(\mathrm{t}-1)+\lambda 4 P S \& A V T(\mathrm{t}-1)+\mu \mathrm{t} \quad(12)
\end{aligned}
$$

Here, the above developed model shown in equation $[12]^{6}$ covers the short-run and long-run dynamics to make specifications given in equations [1, 2 \& 3] labelled as asymmetric or non-linear ARDL.

\section{Results \& Discussions}

In this paper, two methodologies (ARDL \& NARDL) have been used to test the linear \& non-linear/bi-directional links between the selected components of GI and SMD of Pakistan for better and relevant decisions. The analysis, its results and relevant discussion begin as;

\subsection{Descriptive Statistics, Correlation Matrix \& Unit Root Test}

Table 2 covers descriptive statistics. It provides information about Mean and Median values of all variables in the model. The maximum Mean/Median values on the basis of log

\footnotetext{
${ }^{6}$ For extensive derivation of the model, see the methodology used by Shin, Yu, and Greenwood-Nimmo (2014) 
values are for regulatory quality $(R Q)$ with $1.45 \& 1.46$ respectively, while maximum range of variation is observed in LPS\&AVT that is 1.38 . Higher range of dispersion indicates that political stability and absence of violence/terrorism plays a key role in economic and financial development of Pakistan. The other two variables ( $R O L \& R Q$ ) have almost similar variations i.e., 0.39 . while, $V \& A$ indicates value of dispersion at 0.58 . The range of $S M D$ is 0.87 , it shows higher variation rate in this statistical model. Same is true and can be tested in case of S.D. The Skewness values for $R Q, P S \& A V T$ and $V \& A$ indicate fairly symmetrical data, while $R O L$ \& $S M D$ indicate that data is moderately skewed (Emara \& El Said, 2021). The Kurtosis values of $R O L, R Q \& V \& A>3.00$, that indicate data set has heavier tails than a normal distribution, while SMD and PS\&AVT indicate lighter tails than normal distribution as kurtosis <3.00 (Jareño et al., 2020; Masood et al., 2020; Modugu \& Dempere, 2020).

\section{Table 2: Descriptive Statistics for Governance Indicators \& SMD of Pakistan}

\begin{tabular}{lccccc}
\hline \hline & LSMD & LROL & LRQ & LPS_AVT & LV_A \\
\hline \hline Mean & 1.327291 & 1.395351 & $\mathbf{1 . 4 4 8 3 6 4}$ & 0.553000 & 1.387769 \\
Median & 1.331486 & 1.389507 & $\mathbf{1 . 4 5 9 4 5 8}$ & 0.484300 & 1.404014 \\
Maximum & 1.660384 & 1.647464 & 1.636609 & $\mathbf{1 . 3 5 8 5 0 8}$ & 1.682747 \\
Minimum & 0.790215 & 1.250138 & 1.248806 & $\mathbf{- 0 . 0 2 3 2 5}$ & 1.111777 \\
Std. Dev. & 0.240567 & 0.091946 & 0.080666 & $\mathbf{0 . 4 8 6 0 4 5}$ & 0.125018 \\
Skewness & -0.566818 & 0.975252 & -0.212787 & 0.338631 & -0.05808 \\
Kurtosis & 2.410399 & 3.770697 & 4.093131 & 1.736420 & 3.544671 \\
\hline
\end{tabular}

Table 3 shows the covariance correlation matrix. The matrix indicates negative link of all independent variables with $S M D$ of Pakistan except $V \& A$. Interestingly, PS\&AVT is the only variable that shows negative \& significant impact on SMD of Pakistan with coefficient = 0.4956 . The negative relationship between variables indicates that certain other factors exist that impact this link between WGI \& SMD. The analysis extends further that $R Q$ significantly impact $R O L$ with positive coefficient $=0.54$ and $P S \& A V T$ significantly impacts $R O L$ (coefficient=0.69), while $V \& A$ significantly impacts $R O L \& R Q$ with respective coefficients of $0.49 \& 0.83$ respectively. It is also worth-mentioning that ROL significantly \& positively impacts $R Q, P S \& A V T$ and $V \& A$ (Ming \& Jais, 2021). The discussion indicates bi-directional causality between explanatory variables in case of Pakistan. The latest studies that support and wet this discussion include (Husnain et al., 2020; Lakshmi et al., 2021; Ouedraogo \& Sawadogo, 2020; Uzum et al., 2021).

Table 3: Correlation Matrix for Governance Indicators \& SMD of Pakistan

\begin{tabular}{l|ccccc}
\hline \hline Correlation & LSMD & LROL & LRQ & LPS\&AVT & LV\&A \\
\hline LSMD & 1.000000 & & & & \\
LROL & -0.303930 & 1.000000 & & & \\
& 0.1397 & ---- & & & \\
LRQ & -0.079736 & 0.538775 & 1.000000 & & \\
& 0.7048 & $\mathbf{0 . 0 0 5 5}$ & $-\overline{0}$ & & \\
LPS_AVT & -0.495671 & 0.687324 & 0.065141 & 1.000000 & \\
& $\mathbf{0 . 0 1 1 7}$ & $\mathbf{0 . 0 0 0 1}$ & 0.7571 & ---- & 1.000000 \\
LV_A & 0.006495 & 0.491427 & 0.827851 & 0.052010 & ---- \\
& 0.9754 & $\mathbf{0 . 0 1 2 6}$ & $\mathbf{0 . 0 0 0 0}$ & 0.8050 & \\
\hline
\end{tabular}

Table 4: Unit-Root Test, Durbin-Watson Stats and Adjusted $\mathbf{R}^{2}$ Statistics

\begin{tabular}{|c|c|c|c|c|c|c|}
\hline $\begin{array}{c}\text { Name of } \\
\text { Variable }\end{array}$ & $\begin{array}{c}\text { Unit Root } \\
\text { Test }\end{array}$ & Trend/Intercept & $\begin{array}{c}\text { Adj. R- } \\
\text { Squred }\end{array}$ & DW-Stats & $\begin{array}{c}\text { LOG-Likely } \\
\text { Ratio }\end{array}$ & S.D. \\
\hline SMD & $\mathrm{I}(0)$ & $\begin{array}{c}\text { with Trend \& } \\
\text { Intercept }\end{array}$ & 0.4400 & 2.1700 & 15.3700 & 0.1800 \\
\hline PS\&ATV & $\mathrm{I}(1)$ & With Intercept & 0.6000 & 1.9500 & $\mathbf{- 0 . 2 1 0 0}$ & 0.4000 \\
\hline RQ & $\mathrm{I}(0)$ & With Intercept & 0.6200 & $\mathbf{1 . 6 8 0 0}$ & 37.3800 & 0.0756 \\
\hline ROL & $\mathrm{I}(0)$ & With Intercept & $\mathbf{0 . 3 6 0 0}$ & 2.1700 & 34.7400 & 0.1100 \\
\hline V\&A & $\mathrm{I}(0)$ & With Intercept & 0.6400 & 1.9700 & 38.8900 & $\mathbf{0 . 0 7 3 2}$ \\
\hline
\end{tabular}

Table 4 discusses the results of unit root test, values of adjusted $R^{2}$, values of DWstats, S.D., Log-likely ratios and intercept with trends. The dependent variable, SMD is I(0), with trend \& intercept, having adjusted $\mathrm{R}^{2}=0.44$, with negative auto-correlation as shown by $D W$-stats $=2.17$. The S.D. for SMD is 0.18 with higher Log-likely value $=5.37$. All dependent variables are $I(0)$ except PS\&ATV, that is $I(1)$, with intercept \& no trend. None of the variables 
in model is $I(2)$. All explanatory variables with positive serial-correlation as shown by the values of DW-statistics except ROL (Risal \& Koju, 2021). The S.D. indicates maximum deviation in PS\&ATV, as already tested in Table-2 and it also suffers from negative Loglikelihood ratio. The other three variables having higher Log-likelihood values indicate the goodness of fit. The predictive power of four variables as shown by Table-4 has not been significant, as adjusted $R$-Squared $<0.70$ (Hue et al., 2019).

\subsection{Results of Pair-wise Granger Causality}

Table 5 discusses pair-wise results of Granger causality. Table shows $R O L$ does not Granger cause SMD of Pakistan, but it does Granger cause RQ \& V\&A at $10 \%$. ROL also Granger cause $P S \& A V T$ at $\mathrm{p}$-value $=0.05$. It denotes that $R O L$ provides a basis to different variables that directly affect SMD of Pakistan (Uzelac et al., 2020). The $2^{\text {nd }}$ variable, $R Q$ does Granger cause $S M D$ of Pakistan bi-directionally at highly significant $p$-values. It does not Granger cause $R O L \& V \& A$, but it does Granger cause PS\&AVT at $\mathrm{p}$-value $=0.05$ (Modugu \& Dempere, 2020). The $3^{\text {rd }}$ variable, PS\&AVT does not Granger cause SMD. It gives opposite results against the result of Table-3. It also does not Granger cause $R Q$ and V\&A. Though it Granger cause $R O L$ at $10 \%$ uni-directionally (Saeed Meo, 2017). The $4^{\text {th }}$ variable $V \& A$ does Granger cause SMD and PS\&AVT at $10 \%$, it does not Granger Cause regulatory quality \& rule of law (H. Khan et al., 2020; Ming \& Jais, 2021).

The brief discussion on Table- 5 demands an in-depth investigation to find out hidden association between variables, as this can be further tested by using $A R D L$ (uni-directional) and NARDL (bi-directional) frame to address asymmetries. For better predictions, the results of bi-directional causality \& low values of adjusted $R^{2}$, must be investigated into its POS \& NEG partial sums of decomposition of variables to enhance the predictive power of selected components of GI and to develop graphical asymmetric multipliers for cumulative dynamics called AMCD graphs (Allen \& McAleer, 2020; Okere, Muoneke, \& Onuoha, 2021; Phong, Van, \& Bao, 2019).

\section{Table 5: Results of Granger Causality}

\begin{tabular}{lccc}
\hline \hline LROL does not Granger Cause LSMD & 23 & 1.25637 & 0.3085 \\
LSMD does not Granger Cause LROL & & 0.98823 & 0.3915 \\
\hline \hline LRQ does not Granger Cause LSMD & 23 & $\mathbf{4 . 9 1 3 0 1}$ & $\mathbf{0 . 0 1 9 8}$ \\
LSMD does not Granger Cause LRQ & & 7.12761 & $\mathbf{0 . 0 0 5 2}$ \\
\hline \hline LPS_AVT does not Granger Cause LSMD & 23 & 0.52822 & 0.5985 \\
LSMD does not Granger Cause LPS AVT & & 0.30050 & 0.7441 \\
\hline \hline LV_A does not Granger Cause LSMD & 23 & $\mathbf{3 . 2 9 7 5 4}$ & $\mathbf{0 . 0 6 0 2}$ \\
LSMD does not Granger Cause LV_A & & $\mathbf{4 . 2 4 3 2 9}$ & $\mathbf{0 . 0 3 0 9}$ \\
\hline \hline LRQ does not Granger Cause LROL_ & 23 & 0.85436 & 0.4421 \\
LROL does not Granger Cause LRQ & & $\mathbf{2 . 6 1 5 1 9}$ & $\mathbf{0 . 1 0 0 7}$ \\
\hline \hline LPSAVT does not Granger Cause LROL & $\mathbf{2 3}$ & $\mathbf{2 . 8 9 0 7 3}$ & $\mathbf{0 . 0 8 1 5}$ \\
LROL does not Granger Cause LPS AVT & & $\mathbf{3 . 6 3 2 1 7}$ & $\mathbf{0 . 0 4 7 3}$ \\
\hline \hline LV_A does not Granger Cause LROL & 23 & 2.18986 & 0.1409 \\
LROL does not Granger Cause LV_A & & $\mathbf{3 . 3 5 1 0 7}$ & $\mathbf{0 . 0 5 7 9}$ \\
\hline \hline LPS_AVT does not Granger Cause LRQ & 23 & 0.48505 & 0.6235 \\
LRQ does not Granger Cause LPS_AVT & & $\mathbf{3 . 7 9 8 5 8}$ & $\mathbf{0 . 0 4 2 0}$ \\
\hline \hline LV_A does not Granger Cause LRQ & 23 & 0.46957 & 0.6327 \\
LRQ does not Granger Cause LV A & & 0.95898 & 0.4020 \\
\hline \hline LV_A does not Granger Cause LPS_AVT & $\mathbf{2 3}$ & $\mathbf{3 . 3 1 0 4 8}$ & $\mathbf{0 . 0 5 9 7}$ \\
LPS_AVT does not Granger Cause LV_A & & 2.23292 & 0.1361 \\
\hline \hline
\end{tabular}

\subsection{Results of ARDL}

Table 6 shows the results of $A R D L$ framework. Starting from DW Statistics, it shows the presence of negative auto-correlation in residuals as DW-stats lies outside the upper range $(1.70<D W-S t a t s<2.30)$. Table shows adjusted $R^{2}$ statistics $=0.91$, denoting an excellent 'predictive power' of the model to explain SMD of Pakistan. The first explanatory variable is $R O L$, showing coefficient value $=0.77$, but insignificant $\mathrm{p}$-value $=0.11$. It extends the results of Table-3 \& Table-5 that $R O L$ is a supportive/complementary factor that facilitates the impact of 'other variables' on SMD of Pakistan (M. A. Khan et al., 2020; Luong et al., 2020). The $2^{\text {nd }}$ variable, regulatory quality $(R Q)$, though highly significant but impacts $S M D$ of Pakistan with 
negative coefficient=-3.65. It denotes those extra ordinary stringent regulations; complex or complicated procedures do not promote $S M D$ of Pakistan. The role of $R Q$ remains significant over the years but its impact decreases with lower coefficient values as increase in number of Lags occurs (Nguyen et al., 2020; Umar \& Nayan, 2018).

Table- 6 shows interesting result of $3^{\text {rd }}$ variable i.e., PS\&AVT, that shows insignificant impact on SMD. Its impact becomes significant/relevant with the performance of institutional factors (Abdul Rahman \& Saif, 2020; Uzelac et al., 2020). The $4^{\text {th }}$ variable is V\&A (voice and accountability). It shows highly significant impact on SMD of Pakistan with coefficient value of +1.40 . Voice and accountability along with regulatory quality and PS\&AVT and supported by $R O L$ jointly affect $S M D$ of Pakistan and the variables suggest effective synchronization of the model variables that will facilitate a sustainable development in the equity market of Pakistan (Boadi \& Amegbe, 2017; Ming \& Jais, 2021; Modugu \& Dempere, 2020).

Table 6: Results of ARDL for Governance Indicators \& SMD of Pakistan

\begin{tabular}{lrrrr}
\hline \hline Variable & Coefficient & Std. Error & t-Statistic & Prob.* $^{*}$ \\
\hline \hline LSMD(-1) & -0.074759 & 0.148536 & -0.503307 & 0.6256 \\
LSMD(-2) & 0.430902 & 0.137392 & 3.136292 & 0.0106 \\
LSMD (-3) & 0.434118 & 0.177112 & 2.451098 & 0.0342 \\
LROL & 0.769947 & 0.441212 & 1.745074 & 0.1116 \\
LRQ & -3.654123 & 0.529262 & -6.904179 & 0.0000 \\
LRQ (-1) & -0.227028 & 0.395351 & -0.574244 & 0.5785 \\
LRQ (-2) & -1.468477 & 0.295616 & -4.967512 & 0.0006 \\
LRQ (-3) & -1.814894 & 0.313267 & -5.793450 & 0.0002 \\
LPS AVT & 0.208164 & 0.118710 & 1.753546 & 0.1100 \\
LPS AVT (-1) & -0.199332 & 0.098762 & -2.018310 & 0.0712 \\
LV A & 1.401140 & 0.347309 & 4.034276 & 0.0024 \\
C & 7.696882 & 1.193406 & 6.449506 & 0.0001 \\
\hline \hline R-squared & 0.955628 & Mean dependent var & 1.350013 \\
Adjusted R-squared & 0.906820 & S.D. dependent var & 0.241156 \\
S.E. of regression & 0.073614 & Akaike info criterion & -2.077513 \\
Log likelihood & 34.85264 & Hannan-Quinn criter. & -1.937322 \\
F-statistic & 19.57907 & Durbin-Watson stat & 2.477134 \\
\hline \hline
\end{tabular}

\subsection{Results of Non-linear ARDL}

The core rationale of this research paper has been covered in Table-7 to show results under NARDL frame. The discussion starts from rule of law, decomposed into POS \& NEG partial sums. Its shows that by increasing one unit in $R O L, S M D$ of Pakistan increases by 2.43 unit. It also denotes $L R O L \_N E G$ has significant impact on $S M D$ at $10 \%$, denoting that one unit decrease in ROL will increase SMD of Pakistan by 1.45 units. Hence, SMD is a POSITIVE Function of both POS \& NEG changes in ROL as both the coefficients ( $2.43 \& 1.45$ ) are positive w.r.t. direction and magnitude. Rather, systematic decline in prevailing rule of law has positive and significant impact on equity market, but deterioration is not desirable. Statistically speaking, SMD of Pakistan is a POSITIVE function of ROL. The results of Table-7 \& Table-6 under NARDL \& ARDL bound testing for $R O L$ almost show same direction, that better, relaxed and relevant law and order situation promotes stock market performance in Pakistan (Bilan et al., 2019; M. A. Khan et al., 2018; Uzelac et al., 2020).

The $2^{\text {nd }}$ variable is regulatory quality $(R Q)$, decomposed into $L R Q P O S$ that shows a significant and positive impact on SMD of Pakistan at $10 \%$, while $L R Q P O S_{-}(-1)$ supports that consistent improvement in the quality of regulations will facilitate $S M D$ on long-run basis with higher \& positive coefficients while $L R Q-N E G$ with highly significant $\mathrm{p}$-value and negative coefficient (-7.33) shows that when regulatory quality decreases by one unit for the institutions, the performance of SMD decreases by 7.33 units. Hence, the link is positive. The results in Table-6 have opposite recommendations that indicate $R Q$ does promote $S M D$ of Pakistan, though its role decreases due to lower coefficient values, as number of lags increase but remains highly significant. This again is a major bone of difference while formulating any new policy or modifying any old strategy (M. M. Ahmed, 2021; Bilan et al., 2019; Ellahi et al., 2021; M. A. Khan et al., 2020; Naseer, Khan, Popp, \& Oláh, 2021; Umar \& Nayan, 2018).

The $3^{\text {rd }}$ explanatory variable that is most relevant to present circumstances of Pakistan is PS\&AVT. The political stability and control on violence and terrorism has significant and 
positive impact on SMD of Pakistan with coefficient value of 1.10 , but the impact of decrease in $P S \& A V T$ has been highly significant and a prompt on SMD with minimum standard errors, indicating decline in PS\&AVT creates immediate shocks to SMD (Abdul Rahman \& Saif, 2020; M. A. Khan et al., 2018). The discussion ends with the $4^{\text {th }}$ variable i.e., voice and accountability. Here, $L V \& A \_P O S$ has been highly significant with negative coefficient $(-4.80)$. It refers to strict accountability rules does not support $S M D$ of Pakistan. It denotes when $V \& A$ increases by one unit, $S M D$ decreases by 4.80 units, hence relationship is negative (Boadi \& Amegbe, 2017; Modugu \& Dempere, 2020). While, LV\&A_POS(-1), also wetted previous discussion. At the same time, $L V \& A(N E G)$, positively \& significantly impacts $S M D$ with coefficient of +3.98 . It refers relaxed regulations/rules that directly promote financial markets in Pakistan with minimum government intervention (M. A. Khan et al., 2018). As with one unit decrease in V\&A, SMD will increase by 3.98 units. Hence, the association between SMD of Pakistan and $V \& A$ is negative. The results in Table- 7 are again in opposite direction compared to the results of ARDL frame in Table- 6 due to significant differences in coefficients \& standard error estimates as discussed in next section (H. Khan et al., 2020; Modugu \& Dempere, 2020).

Table 7: Results of Non-Linear ARDL For GI and SMD of Pakistan

\begin{tabular}{lrrrr}
\hline \hline Variable & Coefficient & Std. Error & t-Statistic & Prob.* $^{*}$ \\
\hline \hline LSMD (-1) & -0.124390 & 0.149550 & -0.831760 & 0.4271 \\
LROL_POS & 2.428809 & 0.836291 & 2.904264 & 0.0175 \\
LROL_NEG & 1.449286 & 0.740405 & 1.957425 & 0.0820 \\
LROL_NEG (-1) & 2.234572 & 0.861794 & 2.592930 & 0.0291 \\
LRQ_POS & 1.812455 & 0.877853 & 2.064646 & 0.0690 \\
LRQ_NEG & -7.326588 & 1.242622 & -5.896073 & 0.0002 \\
LRQ_NEG(-1) & -2.587893 & 1.327618 & -1.949275 & 0.0831 \\
LPS_AVT_POS & 1.098912 & 0.166958 & -0.292963 & 0.0062 \\
LPS_AVT_NEG & -3.052139 & 0.176308 & 0.295726 & 0.0091 \\
LPS_AVT_NEG (-1) & -0.299001 & 0.214481 & -1.394067 & 0.1968 \\
LV_A_POS & -4.800608 & 1.059303 & -4.531856 & 0.0014 \\
LV_A_NEG & 3.977683 & 0.580490 & 6.852280 & 0.0001 \\
LV_A_NEG (-1) & 0.600564 & 0.656357 & 0.914996 & 0.3841 \\
C & 1.016333 & 0.187209 & 5.428864 & 0.0004 \\
\hline \hline R-squared & 0.968567 & Mean dependent var & 1.382193 \\
Adjusted R-squared & 0.943164 & S.D. dependent var & 0.220632 \\
S.E. of regression & 0.054473 & Akaike info criterion & -2.216627 \\
Log likelihood & 39.49121 & Hannan-Quinn criter. & -2.042800 \\
F-statistic & 21.33276 & Durbin-Watson stat & 2.321213 \\
\hline \hline
\end{tabular}

\subsection{Comparative Analysis of ARDL \& NARDL in Descriptive Terms}

The lower section of Table- 6 indicates adjusted $R^{2}=0.91, \mathrm{SD}=0.24, \mathrm{~S}$.E. of regression of 0.07 , Mean value of 1.35 , and Log-likelihood $=34.85$ compared to the results of Table-7, that indicates better adjusted $\mathrm{R}^{2}=0.94$, lesser values of S.D. \& S.E. of regression $(0.22 \& 0.05$ respectively), higher Mean=1.38 \& higher Log-Likelihood=39.49 under NARDL frame. It demands an extended investigation of auxiliary macroeconomic country-specific factors in due course of time for more consistent, progressive and smooth operations of stock market of Pakistan (Eldomiaty et al., 2016; Ullah \& Jan, 2020).

The discussion in Section 4.4 and 4.5 helps to conclude that the link between selected components of Governance Index and SMD of Pakistan is not of rather symmetrical nature (Bhuiyan \& Chowdhury, 2020; Ellahi et al., 2021). This shows that the Index components do not impact SMD significantly and symmetrically, rather it depends on synchronized \& wellconnected macro-economic variables that magnify the impact of decomposition of POS \& NEG partial changes in multipliers of various components of Governance Index as shown in graphical ACDM (asymmetric cumulative dynamic multipliers) in section 4.8 (Allen \& McAleer, 2020; Jareño et al., 2020; Meo, Chowdhury, Shaikh, Ali, \& Masood Sheikh, 2018; Saeed Meo, Hafeez, Shaikh, \& Shahid, 2018).

\subsection{ARDL \& NARDL Long Run Form \& Bounds Test}

Bound-testing/F-statistics for ARDL \& NARDL have been shown in Table 8 in parallel form. The F-statistics for ARDL and NARDL is $6.6956 \& 10.4105$ respectively, that shows a 
strong cointegration (long-run bound testing), as F-stats value is well above tabulated upperbound $^{7}$ values of $\mathrm{I}(1) @ 10 \%, 5 \%, 2.50 \% \& 1.00 \%$ respectively. It indicates that model has predictive power to influence SMD of Pakistan for long-run under both techniques.

Table 8: Symmetric and Asymmetric F-Bounds Test Results

\begin{tabular}{llllllllll}
\hline ARDL & & \multicolumn{7}{c}{ NARDL } \\
\hline Test- Stats & Value & Sig. & I (0) & I (1) & Test- Stats & Value & Sig. & I (0) & I (1) \\
\hline F-Stats & $\mathbf{6 . 6 9 5 7}$ & $10 \%$ & 2.45 & $\mathbf{3 . 5 2}$ & F-Stats & $\mathbf{1 0 . 4 1 0 5}$ & $10 \%$ & 1.95 & $\mathbf{3 . 0 6}$ \\
K & 4 & $5 \%$ & 2.86 & $\mathbf{4 . 0 1}$ & K & 8 & $5 \%$ & 2.22 & $\mathbf{3 . 3 9}$ \\
& & $2.50 \%$ & 3.25 & $\mathbf{4 . 4 9}$ & & & $2.50 \%$ & 2.48 & $\mathbf{3 . 7 7}$ \\
& & $1.00 \%$ & 3.74 & $\mathbf{5 . 0 6}$ & & & $1.00 \%$ & 2.79 & $\mathbf{4 . 1 1}$ \\
\hline
\end{tabular}

\subsection{Diagnostic Inspection for ARDL \& NARDL Frames}

Table-9 covers the necessary diagnostic measures for ARDL \& NARDL. The Table shows the results of selected diagnostics under three heads (i) residual diagnostics (ii) stability diagnostics (iii) coefficient diagnostics. The Serial-1 of Table-9 shows the results of BreuschGodfrey Serial Correlation LM test with respective $p$-values for $A R D L[0.0004<0.05]$, while $p$ value for $N A R L D$ is $0.008<0.05$. It denotes presence of serial-correlation. It denotes the absence of efficient OLS estimator, hence, no BLUE coefficients for OLS. It indicates that any two given variables are inter-dependent \& confirms bidirectional causality. The Serial-2 in the Table shows normality of residuals under Jarque-Bera test with no issue regarding data normality. Under ARDL \& NARDL frame as respective $p$-values for Breusch-Pagan-Godfrey Test are greater than 0.05 as shown in Table-9 under Serial-3 indicate no issue of heteroskedasticity in the model (Chaudhry et al., 2021). Table-9 (Serial-4) also shows the $p$ values for t-stats (Banerjee \& Urga, 2005) and F-stats (Pesaran, Shin, \& Smith, 2001) for Ramsey RESET Test. The respective $p$-values under ARDL \& NARDL are $0.2399 \& 0.4041$ respectively, that are greater than 0.05 . The values denote correct and valid specification of the model (Chen et al., 2020; Ibrahim \& Alagidede, 2018).

\section{Table 9: Diagnostic Inspection for GI and SMD of Pakistan}

\begin{tabular}{|c|c|c|c|c|c|}
\hline \multirow[b]{2}{*}{ Diagnostic Tests } & \multirow[b]{2}{*}{$\begin{array}{l}\text { Problem } \\
\text { Addressed }\end{array}$} & \multicolumn{3}{|c|}{ ARDL } & \multirow{2}{*}{$\begin{array}{l}\text { NARDL } \\
\text { Decision }\end{array}$} \\
\hline & & $\begin{array}{l}\text { P-Value } \\
=[\mathrm{X} 2]\end{array}$ & Decision & $\begin{array}{l}\text { P-Value } \\
=[\mathrm{X} 2]\end{array}$ & \\
\hline $\begin{array}{l}\text { 1. Breusch- } \\
\text { Godfrey LM Test }\end{array}$ & $\begin{array}{l}\text { Serial } \\
\text { Correlation }\end{array}$ & $0.0004<0.05$ & $\begin{array}{l}\text { Serial correlation } \\
\text { Does Exist }\end{array}$ & $\begin{array}{l}0.0018< \\
0.05\end{array}$ & $\begin{array}{l}\text { Serial correlation } \\
\text { Does Exist }\end{array}$ \\
\hline $\begin{array}{l}\text { 2. Jarqu-Bera } \\
\text { Test }\end{array}$ & $\begin{array}{l}\text { Data } \\
\text { Normality }\end{array}$ & $0.5934>0.05$ & $\begin{array}{l}\text { Residuals Normally } \\
\text { Distributed }\end{array}$ & $\begin{array}{l}0.2628> \\
0.05\end{array}$ & $\begin{array}{l}\text { Residuals are } \\
\text { Normally Distributed }\end{array}$ \\
\hline $\begin{array}{l}\text { 3. Breusch-Pagan- } \\
\text { Godfrey Test }\end{array}$ & $\begin{array}{l}\text { Heteroske- } \\
\text { dasticity }\end{array}$ & $\begin{array}{l}0.5761> \\
0.05\end{array}$ & No Hetero Exist & $\begin{array}{l}0.866> \\
0.05\end{array}$ & No Hetero Exist \\
\hline $\begin{array}{l}\text { 4. Ramsey } \\
\text { RESET Test }\end{array}$ & $\begin{array}{l}\text { Model } \\
\text { Specification }\end{array}$ & $0.2399>0.05$ & $\begin{array}{l}\text { Model is Correctly } \\
\text { Specified }\end{array}$ & $\begin{array}{l}0.4041> \\
0.05\end{array}$ & $\begin{array}{l}\text { Model is Correctly } \\
\text { Specified }\end{array}$ \\
\hline $\begin{array}{l}\text { 5.Variance } \\
\text { Inflation Factor } \\
\text { [VIF] }\end{array}$ & $\begin{array}{l}\text { Multicolli- } \\
\text { nearity }\end{array}$ & $\begin{array}{l}\text { All VIF }<10 \\
\text { Except } \\
P S \& A V T\end{array}$ & $\begin{array}{l}\text { No Issues of } \\
\text { Multicollinearity }\end{array}$ & $\begin{array}{l}\text { All VIF } \\
\text { are }>10\end{array}$ & $\begin{array}{l}\text { Multicollinearity } \\
\text { Does Exist }\end{array}$ \\
\hline 6. Wald Test & $\begin{array}{l}\text { Coefficients } \\
\text { Test }\end{array}$ & $0.07>0.05$ & $\begin{array}{l}\text { Variables jointly } \\
\text { and statistically } \\
\text { NOT Significant }\end{array}$ & $\begin{array}{l}0.008 \\
<0.05\end{array}$ & $\begin{array}{l}\text { Variables jointly and } \\
\text { statistically } \\
\text { Significant }\end{array}$ \\
\hline $\begin{array}{l}\text { 7. CUSUM \& } \\
\text { CUSUMSQ Test }\end{array}$ & $\begin{array}{l}\text { Stability } \\
\text { Test }\end{array}$ & N.A. & Model is Stable & N.A. & $\begin{array}{l}\text { Model is NOT } \\
\text { Stable Due to Shock }\end{array}$ \\
\hline $\begin{array}{l}\text { 8. Coint-Eq }(-1) \text { * } \\
\text { for } E C \text { regression }\end{array}$ & $\begin{array}{l}\text { Long Run } \\
\text { Bounds }\end{array}$ & -0.3234 & $\begin{array}{l}\text { SOA is } \mathbf{3 2 . 3 4} \% \\
\text { towards Mean }\end{array}$ & -0.6402 & $\begin{array}{l}\text { SOA is } \mathbf{6 4 . 3 4} \% \\
\text { towards Mean }\end{array}$ \\
\hline $\begin{array}{l}\text { 9. Durbin Watson } \\
\text { Statistics }\end{array}$ & $\begin{array}{l}\text { Issue of } \\
\text { Auto } \\
\text { Correlation }\end{array}$ & $2.47>2.30$ & $\begin{array}{l}\text { Issue of } \\
\text { Serial/Auto } \\
\text { Correlation Exist }\end{array}$ & $2.32>2.30$ & $\begin{array}{l}\text { Issue of Serial/Auto } \\
\text { Correlation Exist }\end{array}$ \\
\hline
\end{tabular}

The value of variance inflation factor (VIF) shown in Serial-5 for ARDL is: VIF $<10$, except PS\&AVT. It illustrates no series issue of multicollinearity (MC) in the statistical model. But, in case of NARDL, VIF>10, it indicates existence of multicollinearity issue amid the

\footnotetext{
${ }^{7}$ In this model, conservative approach w.r.t. the selection of critical values as recommended by Shin et al., (2011) has been used, hence selected $\mathrm{k}=3$.
} 
variables (Sutton, Vasnev, \& Gerlach, 2019). Again, refer to Table-9 (Serial-6), it shows results of Wald test. It covers multiple restrictions on hypothesis. The Wald results under $A R D L$ indicates acceptance of Ho that shows the coefficients, being equal and show uni-directional trend. But, in case of NARDL, p-value denotes rejecting Null hypothesis that coefficients are not equal to zero w.r.t. its magnitude, size, direction, degree of strength and intensity. Hence, bi-directional causality exits between variables as they do not jointly impact SMD (Cho et al., 2021; Nkoro \& Uko, 2016). Serial-7 of Table indicates model stability as graphed by using CUSUM \& CUSUMSQ graphs. The graph under NARDL shows abnormal shocks while results of DW-Statistics under Serial-9 of Table-9 indicate the presence of serial/auto correlation under both approaches as DW-statistics $>2.30$.

Lastly, discussing ECM (Error Correction Model), table-9 shows respective values of cointeg-Eq $(-1)^{*}$. The significant $p$-values show speed of adjustment (SOA). The absolute values show that SMD of Pakistan is converging towards its statistical equilibrium (mean value). The convergence rate (SOA), in case of NARDL, is worth-mentioning, $64.02 \%$ Per Annum compared to $32.34 \%$ per annum convergence rate in case of $A R D L$. Hence, NARDL has better predictive power accordingly (K. Ahmed et al., 2021; Bist, 2017; Phong et al., 2019; Shin, Yu, \& Greenwood-Nimmo, 2012).

\subsection{CUSUM \& CUSUMSQ and Asymmetric Cumulative Dynamic Multipliers}

In 1975, Brown, Durbin \& Evans, developed a stability measurement tool CUSUM \& CUSUMSQ, used for the components of GI \& SMD nexus. Figure-1 \& Figure-2 denote the two charts. The charts show market ups and downs (abnormality in market as a result of any macro-economic shock) in the form of regression coefficients. The blue line is within lower and upper $5 \%$ critical lines in case of $A R D L$, hence showing no data abnormality in time series data (Chen et al., 2020).

\section{Figure 1: Graph of CUSUM}

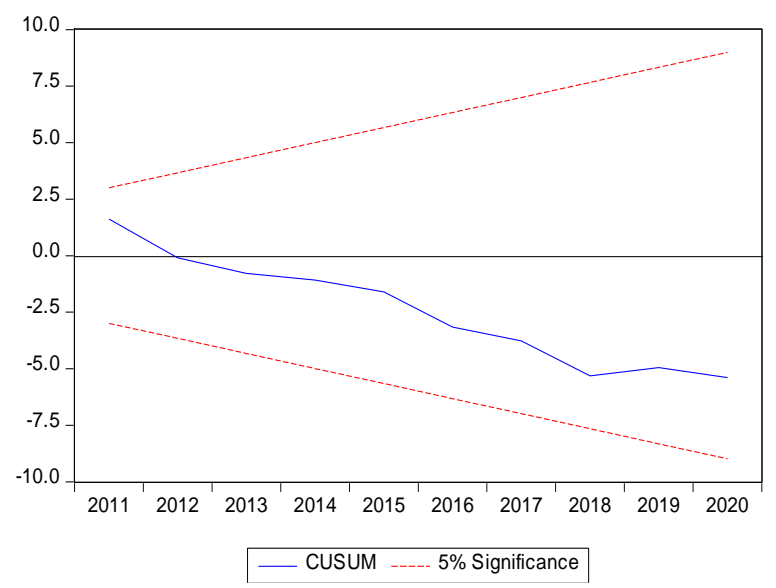

Figure 2: Graph of CUSUMQ

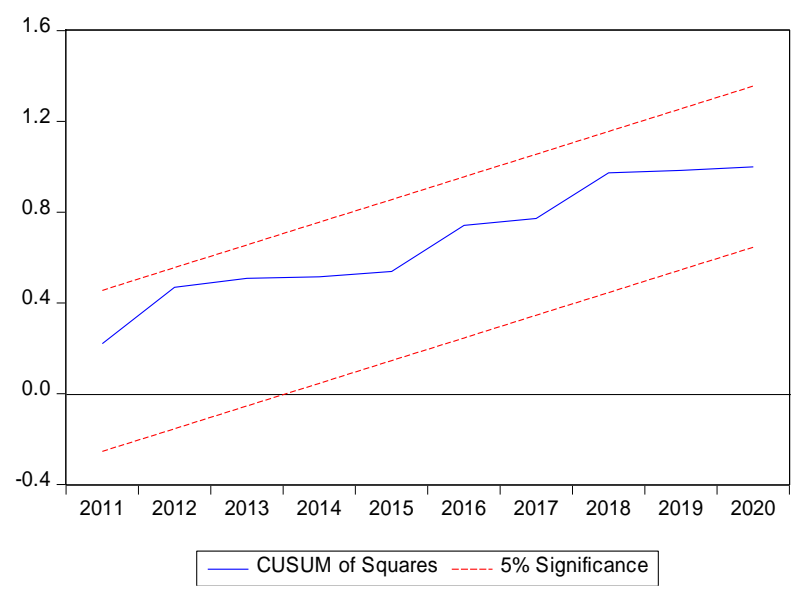

Figure-3 to figure-06, in this study are the proof of asymmetric link amid the variables under NARDL that is basically an asymmetric dynamic graphical presentation of this study. Figure-3 shows bi-directional causality of rule of law into its POS \& NEG partial sums in darkbold-black line \& dark-bold-dashed line above \& below the zero line. Both $L R O L-(+)$ and $L R O L(-)$, started from zero-line, show steep increase and then become parallel to base line and show asymmetry to SMD. While C.I. asymmetric plot remains parallel to base-line, denoting asymmetric behavior of rule of law in predicting SMD of Pakistan (M. M. Ahmed, 2021; M. A. Khan et al., 2020; Phuong, 2020; Uzelac et al., 2020).

Figure-4 shows that both Positive and Negative multipliers of regulatory quality (RQ) lie above base/zero line. Both multipliers started from zero line, but $L R E G Q U A L(-)$ shows a steep

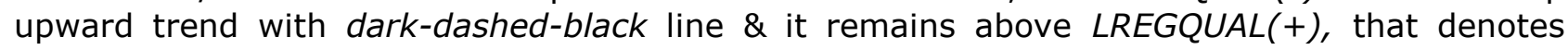
partial NEG sums have significant impact on SMD. While LREGQUAL(+) shows its normal direction with dark-black-bold line. The asymmetric plot with (C.I.), shows a steep upward trend and it crosses both POS \& NEG dynamic cumulative multiplier, showing higher level of asymmetric impact of its NEG decomposition on SMD of Pakistan with a significant negative coefficient value of -7.32 as already discussed in Table-7 (M. A. Khan et al., 2020). 

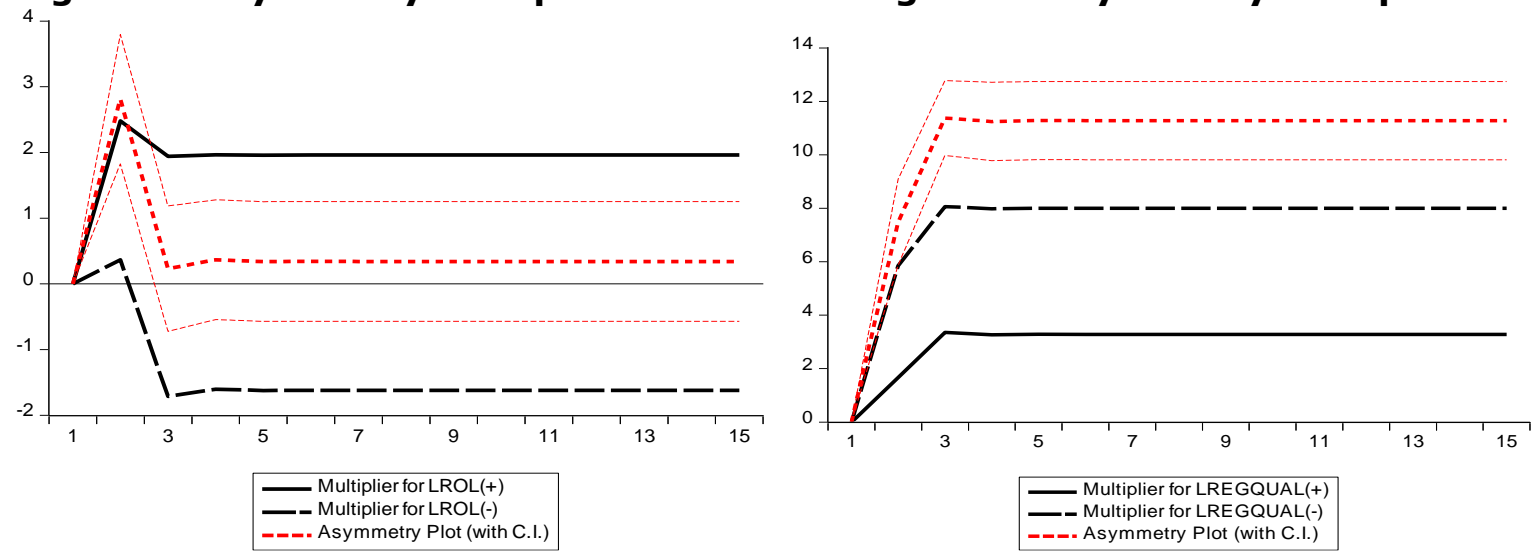

Figure-5 is opposite in direction compared to figure-4 that deals with $3^{\text {rd }}$ variable, voice and accountability $(V \& A)$. Both POS \& NEG multipliers of voice and accountability lie below base line, referring to abnormal reactions of $A C D M$ (asymmetric cumulative dynamics multipliers) of $V \& A$ for $S M D$. The positive multiplier shows steep downward trend and it goes below the negative multiplier. It is interesting to note that asymmetric plot (with C.I.), denoted by dashed-red-color dotted line shows a strait steep downward started from base-line and it went outside the range of $\operatorname{LV} \& A C C(+)$, denoting significant signs of asymmetry amid SMD \& voice and accountability that extend the discussion of Table-7 (Ming \& Jais, 2021; Modugu \& Dempere, 2020). The asymmetric C.I. plot of LV\&A-POS shows significant impact that Granger because SMD compared to $L V \& A-N E G$. The $5 \%$ lower \& upper bound critical dotted-red-lines are also well below the base line to show graphically the effects of asymmetries of voice and accountability on stock market development of Pakistan. The asymmetric plot shows a continuous and significant increased non-linearity (Charfeddine \& Barkat, 2020).

Figure-6 shows asymmetries of PS\&AVT into its POS \& NEG partial decomposition. The behavior of multipliers for PS\&AVT (+) has been denoted by dark-bold-black line that lies below in a negative area, i.e., below the zero line, while PS\&AVT (-) lies above the zero line. Figure- 6 also indicates, both lines started from below the zero line and went into opposite directions showing inverse link of PS\&AVT with SMD. The asymmetric plot (with C.I.), also started from below the zero/base line. After deep downward trend, it shows a parallel trend to zero line but went above the base-line. The decision rule is asymmetric plot (with C.I.) must follow base-line to avoid asymmetry, but it lies above the base line, though it lies in between the POS \& NEG multipliers (Abdul Rahman \& Saif, 2020; Haseeb et al., 2019; Uzelac et al., 2020).

Figure 5: Asymmetry Multipliers for V\&A

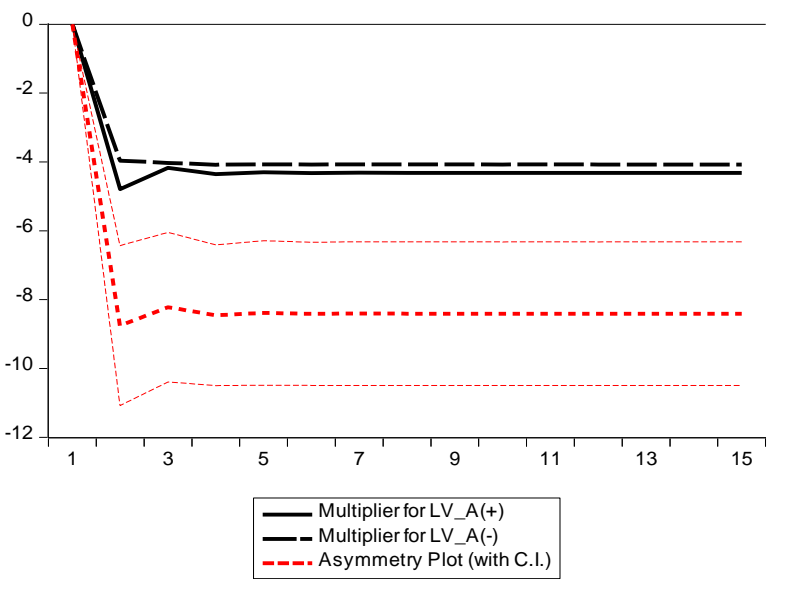

Figure 6: Asymmetry Multipliers for PS\&AVT

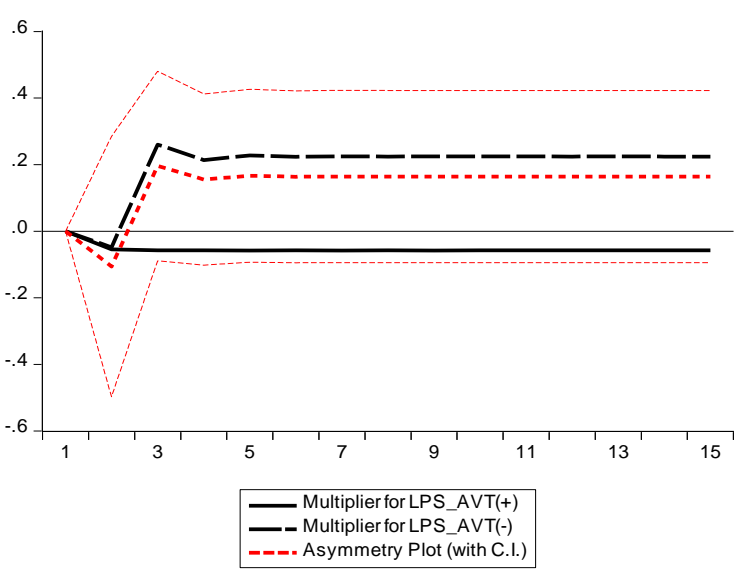




\section{Conclusion and Recommendations}

The scope of this research has been to investigate and elaborate the complex and hidden symmetric and asymmetric dynamics amid the selected components of governance indicators and sustainable SMD of Pakistan by using annual time series data (1996-2020) for 25 years. Governance indicators are actually proxies for various financial and non-financial institutions. The empirical calculations affirm asymmetric associations framed in models and recursive measurements. The asymmetrical investigation shall facilitate sound stock market and mitigate undue volatility and prevailing risks. Ignoring the intrinsic hidden asymmetries will lead to misrepresentative implications regarding sustainable stock market growth of Pakistan. Governance indicators directly matter for stock price volatility/liquidity to promote sustainable SMD of Pakistan. The study indicates that rule of law does not impact SMD under $A R D L$ frame. Regulatory quality of institutions and voice \& accountability significantly impact sustainable $S M D$. While, political stability has no direct and immediate impact on the stock market performance. Under $A R D L$ frame, regulatory quality indicates better predictive power to test the performance of stock market of Pakistan. It denotes the extra ordinary stringent regulations; complex or complicated procedures do not promote SMD of Pakistan. It is worthmentioning that ROL alone does not impact SMD, rather the joint impact of related regulatory and financial institutions is the pre-requisite for developing equity market. Further, V\&A does not work in vacuum, rather it needs support from the other three components. It is advisable for portfolio managers and government agencies to take into consideration the individual behavior of components of governance indicators.

The recommendations given by NARDL frame have been more practical, scientific and valid. It refers that both increase/decrease in rule of law have significant and positive impact on SMD of Pakistan, indicating a significant contrast in policy recommendations. It suggests that magnitude of strictness of laws is not always desirable to flourish financial markets. It can be seen that impact of deterioration in $R Q$ is more harmful to the sustainable financial growth than its improvement. The desirable/technical relaxed quality of regulations is helpful to recruit new investors in the short-run. One of the distinct and vital policy recommendations is PS\&AVT has an immense underlying role in reshaping the performance of stock market of Pakistan. The impact of political instability is prompt \& highly significant on the sustainability of equity market in Pakistan due to extreme chaos among investors. No doubt, the role of voice and accountability in policy formulation cannot be ignored, but relaxed, formal and scientific methods of accountability also play a positive role in achieving sustainable equity market development in Pakistan.

The findings of this study are helpful for regulators and policymakers to recommend stringent reforms pertaining to sustainable improvement in different institution's quality that would significantly affect sustainable stock market returns and liquidity. From future research perspective, the results provide a line of hints of possible dimensions due to POS \& NEG shocks in explanatory variables. The short-run and long-run asymmetries or non-linearities do arise in four components/dimensions of GI, which create joint sustainable increment for SMD. These study further points out the relevant and irrelevant market forces to achieve sustainable SMD in Pakistan. Therefore, policymakers must pay consideration directly to the forces and powers that hinder sustainable performance of local stock market. To better understand these implications of the results, future studies must incorporate all the components of GI. It will be a good tool to magnify the overall sustainable economic growth of Pakistan. This study will practically contribute in policy-making at various operational or strategic level. The findings of this study can be used for designing an 'investment analytical software' that will help to enhance economic sustainability and financial decisions accordingly.

\section{References}

Abdul Rahman, E., \& Saif, A.-D. A. H. A. (2020). The Impact of Political Stability and Absence of Violence/Terrorism on Foreign Direct Investment Flows in the Arab Countries. North American Academic Research, 3(1), 1-20. doi:https://doi.org/10.5281/zenodo.3629946

Abduvaliev, M. (2021). The role of economic integration on the growth of the Tajik economy. (PhD Thesis),

Abeka, M. J., Andoh, E., Gatsi, J. G., \& Kawor, S. (2021). Financial development and economic growth nexus in SSA economies: The moderating role of telecommunication 
development. Cogent Economics \& Finance, 9(1), 1862395. doi:https://doi.org/10.1080/23322039.2020.1862395

Ahmed, K., Khan, B., \& Ozturk, I. (2021). Dynamics between disaggregates of governance and stock market performance in selected South Asia countries. International Journal of Finance \& Economics, 26(1), 802-813. doi:https://doi.org/10.1002/ijfe.1821

Ahmed, M. M. (2021). The Utilization of the Rule of Law for Economic Development in Developing States: The Case of Egypt from Nasser to Mubarak. (Master's Thesis), the American University in Cairo, AUC Knowledge Fountain. Retrieved from https://fount.aucegypt.edu/etds/1512

Ajide, F. M. (2019). Democracy and stock market development: The case of Nigeria. The Journal of Developing Areas, 53(3), 123-139. doi:https://doi.org/10.1353/jda.2019.0042

Al-Gasaymeh, A. (2020). Economic freedom, country risk and cost efficiency in Jordan and the GCC countries. Global Business Review, 21(1), 1-17. doi:https://doi.org/10.1177/0972150917749292

Allen, D. E., \& McAleer, M. (2020). A nonlinear autoregressive distributed lag (NARDL) analysis of west texas intermediate oil prices and the DOW JONES index. Energies, 13(15), 4011. doi:https://doi.org/10.3390/en13154011

Almaharmeh, M. I., Shehadeh, A. A., Iskandrani, M., \& Saleh, M. H. (2021). Audit Quality and Stock Price Synchronicity: Evidence from Emerging Stock Markets. The Journal of Asian $\begin{array}{llll}\text { Finance, Economics } & \text { 833-843. }\end{array}$ doi:https://doi.org/10.13106/jafeb.2021.vol8.no3.0833

Amjad, A., Ehsan, S., Amjad, M., \& Gillani, S. (2021). Impact of Shareholders' Activism on Governance Practices and Firm Performance in Pakistan: A Response for Family Controlled Firms. iRASD Journal of Economics, 3(1), 1-12. doi:https://doi.org/10.52131/joe.2021.0301.0021

Asaad, Z., \& Marane, B. (2020). Corruption, Terrorism and the Stock Market: The Evidence from Iraq. The Journal of Asian Finance, Economics and Business, 7(10), 629-639.

Atiq-ur-Rehman, M., Ditta, A., Nawaz, M. A., \& Bashir, F. (2020). The Lucas Paradox and Institutional Quality: Evidence from Emerging Markets. Review of Economics and Development Studies, 6(2), 461-470. doi:https://doi.org/10.47067/reads.v6i2.223

Banerjee, A., \& Urga, G. (2005). Modelling structural breaks, long memory and stock market volatility: an overview. Journal of Econometrics, 129(1-2), 1-34. doi:https://doi.org/10.1016/j.jeconom.2004.09.001

Bhatti, M. A., Chaudhry, I. S., \& Bashir, F. (2021). Financial Globalization, Output Gap and Foreign Output Gap on inflation: Evidenced from Developing Economies. Journal of Accounting and Finance in Emerging Economies, 7(2), 419-433. doi:https://doi.org/10.26710/jafee.v7i2.1773

Bhuiyan, E. M., \& Chowdhury, M. (2020). Macroeconomic variables and stock market indices: Asymmetric dynamics in the US and Canada. The Quarterly Review of Economics and Finance, 77, 62-74. doi:https://doi.org/10.1016/j.qref.2019.10.005

Bilan, Y., Vasilyeva, T., Lyeonov, S., \& Bagmet, K. (2019). Institutional complementarity for social and economic development. Business: theory and practice, 20(1), 103-115.

Bist, J. P. (2017). Stock market development and economic growth in Nepal: An ARDL representation. Journal of Finance and Economics, 5(4), 164-170.

Boadi, I., \& Amegbe, H. (2017). The link between quality of governance and stock market performance: International level evidence. European Journal of Government and Economics, 6(1), 78-101.

Bogdan, T., \& Lomakovych, V. (2021). Financialization of the global economy: macroeconomic implications and policy challenges for Ukraine. Investment Management and Financial Innovations, 18(1), 151-164.

Charfeddine, L., \& Barkat, K. (2020). Short-and long-run asymmetric effect of oil prices and oil and gas revenues on the real GDP and economic diversification in oil-dependent economy. Energy Economics, 104680. doi:https://doi.org/10.1016/j.eneco.2020.104680

Chaudhry, I. S., Faheem, M., Farooq, F., \& Ali, S. (2021). Financial Development and Natural Resources Dynamics in Saudi Arabia: Visiting 'Resource Curse Hypothesis' by NARDL and Wavelet-Based Quantile-on-Quantile Approach. Review of Economics and Development Studies, 7(1), 101-117. doi:https://doi.org/10.47067/reads.v7i1.325 
Chen, H., Hongo, D. O., Ssali, M. W., Nyaranga, M. S., \& Nderitu, C. W. (2020). The asymmetric influence of financial development on economic growth in Kenya: evidence from NARDL. SAGE Open, 10(1), 2158244019894071. doi:https://doi.org/10.1177/2158244019894071

Chiad, F., \& Sahraoui, H. H. (2021). What Drives Stock Market Development in Arab Countries? Asian Journal of Economics, Finance and Management, 3(1), 36-44.

Chien, F., Sadiq, M., Kamran, H. W., Nawaz, M. A., Hussain, M. S., \& Raza, M. (2021). Comovement of energy prices and stock market return: environmental wavelet nexus of COVID-19 pandemic from the USA, Europe, and China. Environmental Science and Pollution Research, 28, 32359-32373. doi:https://doi.org/10.1007/s11356-021-129382

Chizema, A., \& Pogrebna, G. (2019). The impact of government integrity and culture on corporate leadership practices: Evidence from the field and the laboratory. The Leadership Quarterly, doi:https://doi.org/10.1016/j.leaqua.2019.07.001

$30(5)$

101303.

Cho, J. S., Greenwood-Nimmo, M., \& Shin, Y. (2021). Recent developments of the autoregressive distributed lag modelling framework. Journal of Economic Surveys, 126. doi:https://doi.org/10.1111/joes.12450

Choi, D., Chung, C. Y., Kim, Y.-E., Kim, Y. J., \& Choi, P. M. S. (2020). Sustainable corporate ownership structures and earnings management in the Vietnamese stock market. Sustainability, 12(15), 6089. doi:https://doi.org/10.3390/su12156089

Dang, D., Fang, H., \& He, M. (2019). Economic policy uncertainty, tax quotas and corporate tax burden: Evidence from China. China Economic Review, 56, 101303. doi:https://doi.org/10.1016/j.chieco.2019.101303

Dang, Y. (2021). Comparing the Determines of Economic Growth of 5 Developed Countries and China. Frontiers in Economics and Management Research, 2(1), 7-13.

de Batz, L. (2020). Financial impact of regulatory sanctions on listed companies. European Journal of Law and Economics, 49(2), 301-337. doi:https://doi.org/10.1007/s10657019-09638-1

Diallo, O. K., Mendy, P., \& Burlea-Schiopoiu, A. (2021). A method to test weak-form market efficiency from sectoral indices of the WAEMU stock exchange: A wavelet analysis. Heliyon, 7(1), e05858. doi:https://doi.org/10.1016/j.heliyon.2020.e05858

Dima, B., Barna, F., \& Nachescu, M.-L. (2018). Does rule of law support the capital market? Economic research-Ekonomska istraživanja, 31(1), 461-479. doi:https://doi.org/10.1080/1331677X.2018.1432371

Eichler, S., \& Plaga, T. (2020). The economic record of the government and sovereign bond and stock returns around national elections. Journal of Banking \& Finance, 118, 105832. doi:https://doi.org/10.1016/j.jbankfin.2020.105832

Eldomiaty, T. I., Al Qassemi, T. B. F., Mabrouk, A. F., \& Abdelghany, L. S. (2016). Institutional quality, economic freedom and stock market volatility in the MENA region. Macroeconomics and Finance in Emerging Market Economies, 9(3), 262-283. doi:https://doi.org/10.1080/17520843.2015.1093011

Ellahi, N., Kiani, A. K., Awais, M., Affandi, H., Saghir, R., \& Qaim, S. (2021). Investigating the Institutional Determinants of Financial Development: Empirical Evidence From SAARC Countries. SAGE Open, 11(2). doi:https://doi.org/10.1177/21582440211006029

Emara, N., \& El Said, A. (2021). Financial inclusion and economic growth: The role of governance in selected MENA countries. International Review of Economics \& Finance, 75, 34-54. doi:https://doi.org/10.1016/j.iref.2021.03.014

Fareed, Z., Meo, M. S., Zulfiqar, B., Shahzad, F., \& Wang, N. (2018). Nexus of tourism, terrorism, and economic growth in Thailand: new evidence from asymmetric ARDL cointegration approach. Asia Pacific Journal of Tourism Research, 23(12), 1129-1141. doi:https://doi.org/10.1080/10941665.2018.1528289

Galindo-Manrique, A. F., Pérez-Calderón, E., \& Rodríguez-García, M. d. P. (2021). EcoEfficiency and Stock Market Volatility: Emerging Markets Analysis. Administrative Sciences, 11(2), 36. doi:https://doi.org/10.3390/admsci11020036

Ghardallou, W., \& Boudriga, A. (2014). Financial development and democracy: Is the relationship non-linear. Paper presented at the The Economic Research Forum Working Paper Series.

Gulay, E. (2019). The nexus prevalent in nonlinear finance and growth in the presence of macroeconomic instability in Turkey: Does the stock market really matter? Business and Economic Horizons, 15(1), 1-19. 
Gulyamov, S. (2021). The Institutional and Legal Framework of Emerging Capital Markets: The Experience of CIS Countries. Turkish Journal of Computer and Mathematics Education, 12(4), 1117-1131. doi:https://doi.org/10.17762/turcomat.v12i4.624

Hannah, L. (2019). Corporate governance, accounting transparency and stock exchange sizes in Germany, Japan and ĞAnglo-Saxonğ economies, 1870-1950. Zeitschrift für Unternehmensgeschichte, 64(2), 157-186. doi:https://doi.org/10.1515/zug-2018-0042

Haseeb, M., Wattanapongphasuk, S., \& Jermsittiparsert, K. (2019). Financial Development, Market Freedom, Political Stability, Economic Growth and C [O. sub. 2] Emissions: An Unexplored Nexus in ASEAN Countries. Contemporary Economics, 13(3), 363-375.

Hilliard, J. E., \& Zhang, H. (2019). Regulatory soft interventions in the Chinese market: Compliance effects and impact on option market efficiency. Financial Review, 54(2), 265-301. doi:https://doi.org/10.1111/fire.12189

Husnain, M., Islam, K., \& Ali, W. (2020). Reflection of Regulatory Announcement in Equity Market: Fresh Insight from Oil \& Gas Sector of Pakistan. Journal of Accounting and Finance in Emerging Economies, 6(3), 799-820. doi: https://doi.org/10.26710/jafee.v6i3.1357

Hussain, A., Rafique, M., Khalil, A., \& Nawaz, M. (2013). Macroeconomic determinants of stock price variations: an economic analysis of KSE-100 index. Pakistan Journal of Humanities and Social Sciences, 1(1), 28-46.

Ibrahim, M., \& Alagidede, P. (2018). Effect of financial development on economic growth in sub-Saharan Africa. Journal of Policy Modeling, 40(6), 1104-1125. doi:https://doi.org/10.1016/j.jpolmod.2018.08.001

Islam, F. T., \& Islam, D. (2020). Analyzing the Variability of Growth of Capital Market in Bangladesh: An Empirical Study on the Dhaka Stock Exchange Limited Analyzing the Variability of Growth of the Capital Market in Bangladesh.

Jareño, F., Escribano, A., \& Koczar, M. W. (2020). Non-Linear Interdependencies between International Stock Markets: The Polish and Spanish Case. Mathematics, 9(1), 1-21.

Kamrana, H. W., Nawazb, M. A., \& Rizwan, M. (2020). Vulnerability of Stock Returns and the effects of Covid-19: An Event Study from the Energy Sector of USA. International Journal of Innovation, Creativity and Change, 13(6), 1157-1174.

Kaufmann, D., Kraay, A., \& Mastruzzi, M. (2011). The Worldwide Governance Indicators: Methodology and Analytical Issues. Hague Journal on the Rule of Law, 3(2), 220-246.

Khan, H., Khan, S., \& Zuojun, F. (2020). Institutional quality and financial development: Evidence from developing and emerging economies. Global Business Review, 1-13. doi:https://doi.org/10.1177/0972150919892366

Khan, M. A., Ilyas, R. M. A., \& Hashmi, S. H. (2018). Cointegration between institutional quality and stock market development. NUML International Journal of Business \& Management, 13(2), 90-103.

Khan, M. A., Popp, J., Talib, M. N. A., Lakner, Z., Khan, M. A., \& Oláh, J. (2020). Asymmetric impact of institutional quality on tourism inflows among selected Asian Pacific countries. Sustainability, 12(3), 1-16. doi:https://doi.org/10.3390/su12031223

Kinsella, M., Mehrbani, R., Weiser, W., \& Weiner, D. I. (2020). Executive Actions to Restore Integrity and Accountability in Government.

Kwenda, F., \& Chinoda, T. (2019). The impact of institutional quality and governance on financial inclusion in Africa: A two-step system generalised method of moments approach. Journal of Economic and Financial Sciences, 12(1), 1-9. doi:https://hdl.handle.net/10520/EJC-1d1ff9dc94

Lakshmi, G., Saha, S., \& Bhattarai, K. (2021). Does corruption matter for stock markets? The role of heterogeneous institutions. Economic Modelling, 94, 386-400. doi:https://doi.org/10.1016/j.econmod.2020.10.011

Lepore, L., Paolone, F., \& Cambrea, D. R. (2018). Ownership structure, investors' protection and corporate valuation: The effect of judicial system efficiency in family and nonfamily firms. Journal of Management and Governance, 22(4), 829-862. doi: https://doi.org/10.1007/s10997-018-9405-0

Luong, T. T. H., Nguyen, T. M., \& Nguyen, T. A. N. (2020). Rule of law, economic growth and shadow economy in transition countries. The Journal of Asian Finance, Economics, and Business, 7(4), 145-154. doi:https://doi.org/10.13106/jafeb.2020.vol7.no4.145

Manasseh, C. O., Mathew, T. E., \& Ogbuabor, J. E. (2017). Investigating the nexus between institutional quality and stock market development in Nigeria: An autoregressive 
distributed lag (ARDL) approach. African Development Review, 29(2), 272-292. doi: https://doi.org/10.1111/1467-8268.12256

Mangal, T. K., \& Liu, D.-Y. (2020). The impact of economic freedom on foreign portfolio investments: The case of the Caricom single market and economy. International Journal of Research in Business and Social Science, 9(2), 213-222. doi:https://doi.org/10.20525/ijrbs.v9i2.658

Masood, O., Javaria, K., \& Petrenko, Y. (2020). Terrorism activities influence on financial stock markets: an empirical evidence from United Kingdom, India, France, Pakistan, Spain and America. Insights into Regional Development, 2(1), 443-455.

Mehmood, W., Mohd-Rashid, R., Aman-Ullah, A., \& Zi Ong, C. (2021). Country-Level Institutional Quality and Public Debt: Empirical Evidence from Pakistan. The Journal of Asian Finance, Economics and Business, 8(4), 21-32. doi:https://doi.org/10.13106/jafeb.2021.vol8.no4.0021

Meo, M. S., Chowdhury, M. A. F., Shaikh, G. M., Ali, M., \& Masood Sheikh, S. (2018). Asymmetric impact of oil prices, exchange rate, and inflation on tourism demand in Pakistan: new evidence from nonlinear ARDL. Asia Pacific Journal of Tourism Research, 23(4), 408-422. doi:https://doi.org/10.1080/10941665.2018.1445652

Ming, K. L. Y., \& Jais, M. (2021). Impacts of Macroeconomics Environment and Governance Quality on the Stock Market in the Fourteen Developing Countries. Jurnal Ekonomi Malaysia, 54(3), 1-13.

Mirza, A., Abbas, J., \& Nawaz, M. A. (2020). Which Financial Information Leads to Better Market Valuation and Economic Decision Making in Malaysian Main Market Listed Firms? A Value Relevance Perspective. Pakistan Journal of Social Sciences (PJSS), 40(2), 9951006.

Modugu, K. P., \& Dempere, J. (2020). Country-Level Governance Quality and stock market performance of GCC countries. The Journal of Asian Finance, Economics, and Business, 7(8), 185-195. doi:https://doi.org/10.13106/jafeb.2020.vol7.no8.185

Monsura, M. P., \& Villaruz, R. M. (2021). Long-run Equilibrium Relationship Between Financial Intermediation and Economic Growth: Empirical Evidence from Philippines. The Journal of Asian Finance, Economics and Business, 8(5), 21-27. doi:https://doi.org/10.13106/jafeb.2021.vol8.no5.0021

Montes, G. C., Bastos, J. C. A., \& de Oliveira, A. J. (2019). Fiscal transparency, government effectiveness and government spending efficiency: Some international evidence based on panel data approach. Economic Modelling, 79, 211-225. doi:https://doi.org/10.1016/j.econmod.2018.10.013

Naseer, M. M., Khan, M. A., Popp, J., \& Oláh, J. (2021). Firm, Industry and Macroeconomics Dynamics of Stock Returns: A Case of Pakistan Non-Financial Sector. Journal of Risk and Financial Management, 14(5), 1-18. doi:https://doi.org/10.3390/jrfm14050190

Nguyen, T., Chaiechi, T., Eagle, L., \& Low, D. (2020). Dynamic impacts of SME stock market development and innovation on macroeconomic indicators: A Post-Keynesian approach.

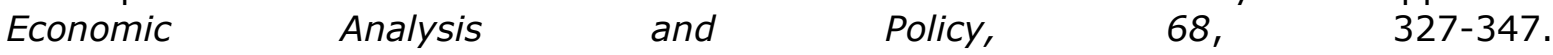
doi:https://doi.org/10.1016/j.eap.2020.10.002

Nirola, N., \& Sahu, S. (2019). The interactive impact of government size and quality of institutions on economic growth-evidence from the states of India. Heliyon, 5(3), e01352. doi:https://doi.org/10.1016/j.heliyon.2019.e01352

Nkoro, E., \& Uko, A. K. (2016). Autoregressive Distributed Lag (ARDL) cointegration technique: application and interpretation. Journal of Statistical and Econometric methods, 5(4), 63-91.

Noshad, M., Amjad, M., Shafiq, M. N., \& Gillani, S. (2019). Performance and Obstacles of SMEs: An Empirical Evidence from BRICS Countries. iRASD Journal of Economics, 1(2), 113-131. doi:https://doi.org/10.52131/joe.2019.0101.0010

Okere, K. I., Muoneke, O. B., \& Onuoha, F. C. (2021). Symmetric and asymmetric effects of crude oil price and exchange rate on stock market performance in Nigeria: Evidence from multiple structural break and NARDL analysis. The Journal of International Trade \& $\begin{array}{lll}\text { Economic Development, 30(6), 930-956. } & \text {. }\end{array}$ doi:https://doi.org/10.1080/09638199.2021.1918223

Ouedraogo, S., \& Sawadogo, H. (2020). Financial development, financial structure and economic growth in the Sub-Saharan African countries. International Journal of Finance \& Economics, 1-24. doi:https://doi.org/10.1002/ijfe.2315 
Pesaran, M. H., Shin, Y., \& Smith, R. J. (2001). Bounds testing approaches to the analysis of level relationships. Journal of applied econometrics, 16(3), 289-326. doi:https://doi.org/10.1002/jae.616

Phong, L. H., Van, D. T. B., \& Bao, H. H. G. (2019). A nonlinear autoregressive distributed lag (NARDL) analysis on the determinants of Vietnam's stock market. Paper presented at the International Econometric Conference of Vietnam.

Phuong, L. (2020). Institutions, microeconomic factors and stock market capitalization: Evidence from the EAP countries. Accounting, 6(5), 817-824.

Razi, N., Zahoor, R., \& Abbas, G. (2021). The Nexus between Fundamental Rights and Necessities of Life: A Case Study of Pakistan. Global Legal Studies Review, 6(1), 9-16. doi:https://doi.org/10.31703/glsr.2021(VI-I).02

Reddy, K. (2019). Pot the ball? Sovereign wealth funds' outward FDI in times of global financial market turbulence: A yield institutions-based view. Central Bank Review, 19(4), 129-139. doi:https://doi.org/10.1016/j.cbrev.2019.08.003

Risal, H. G., \& Koju, P. (2021). Testing the Weak Form of Efficiency in Moscow Exchange. Turkish Journal of Computer and Mathematics Education, 12(3), 5416-5433.

Rysin, V., Galenko, O., Duchynska, N., Kara, N., Voitenko, O., \& Shalapak, A. (2021). Financial Convergence as a Mechanism for Modifying Sectors of the Global Financial Services Market. Universal Journal of Accounting and Finance, 9(1), 65-73.

Saeed Meo, M. (2017). Impact of political stability, government effectiveness and corruption on stock markets of South Asia. Journal of the Punjab University Historical Society, 30(1), 217-229.

Saeed Meo, M., Hafeez, M., Shaikh, G. M., \& Shahid, M. (2018). Asymmetric effect of gold and oil prices on stock market performance in Pakistan: new evidence from asymmetric ARDL cointegration. Journal of Business Strategies, 12(2), 43-64.

Shang, D., Li-Bo, F., Han-Long, L., \& Dong-Liang, Y. (2021). Government Regulation Burden, Strategic Balance, and Corporate Performance. Revista Argentina de Clínica Psicológica, 30(1), 673-684. doi:https://doi.org/10.24205/03276716.2020.2063

Shaohua, Z., Yahya, F., Pham, H., \& Waqas, M. (2021). Do Transparency and Anti-Monopoly Policies Matter for Financial Development? Evidence from a Panel ARDL-PMG Approach. Journal of Applied Economics, 1-16. doi:https://doi.org/10.1080/15140326.2020.1838113

Sheikh, M. F., Shah, S. Z. A., \& Akbar, S. (2018). Firm performance, corporate governance and executive compensation in Pakistan. Applied economics, 50(18), 2012-2027. doi:https://doi.org/10.1080/00036846.2017.1386277

Shi, Y., Ahmed, K., \& Paramati, S. R. (2021). Determinants of stock market development and price volatility in ASEAN plus three countries: The role of institutional quality. International Journal of Finance \& Economics, 26(1), 560-572. doi:https://doi.org/10.1002/ijfe.1804

Shin, Y., Yu, B., \& Greenwood-Nimmo, M. (2012). Modelling Asymmetric Cointegration and Dynamic Multipliers in a Nonlinear ARDL Framework. SSRN Electronic Journal, 40(0), 144.

Sohail, S., Rasul, F., \& Fatima, U. (2017). Is internal and external mechanism of governance enriching the performance of the banking sector of Pakistan? Corporate Governance, 17(4), 629-642. doi:https://doi.org/10.1108/CG-05-2016-0116

Sutton, M., Vasnev, A. L., \& Gerlach, R. (2019). Mixed interval realized variance: A robust estimator of stock price volatility. Econometrics and Statistics, 11, 43-62. doi:https://doi.org/10.1016/j.ecosta.2018.06.001

Tag, M. N. (2021). Judicial institutions of property rights protection and foreign direct investment inflows. International Review of Law and Economics, 65, 105975. doi:https://doi.org/10.1016/j.irle.2020.105975

Udoh, B. E., Jack, A. E., Prince, A. I., Ekeowa, K.-I. L., Ndubuaku, V., \& Samuel, U. E. (2021). Financial Deepening and Economic Growth in Nigeria: ARDL and NARDL Techniques. Universal Journal of Accounting and Finance, 9(4), 667-677.

Ullah, H., \& Jan, S. (2020). Economic Freedom on Stock Market Performance and Liquidity: Evidence from KSE-100 Index Pakistan. NUML International Journal of Business \& Management, 15(1), 110-126.

Umar, B., \& Nayan, S. (2018). Does Regulatory Quality Matters for Stock Market Development? Evidence from Africa. International Journal of Economics and Financial Issues, 8(4), 10-15. 
Uzelac, O., Davidovic, M., \& Mijatovic, M. D. (2020). Legal framework, political environment and economic freedom in central and Eastern Europe: do they matter for economic growth? Post-Communist Economies, 32(6), 697-725. doi:https://doi.org/10.1080/14631377.2020.1722583

Uzum, P., Ikpefan, O. A., Omankhanlen, A. E., Ejemeyovwi, J. O., \& EHIKIOYA, B. I. (2021). Enabling stock market development in Africa: A review of the macroeconomic drivers. Investment Management and Financial Innovations, 18(1), 357-364.

Wang, H., \& Macy, A. (2021). Statutory corporate tax change and the stock market returns: the global experience. Applied Economics Letters, 28(6), 464-469. doi: https://doi.org/10.1080/13504851.2020.1761523

Yusuf, A. M., \& Solmaz, M. (2020). Stock Market Development and Economic Growth: Evidences from China. International Journal of Finance and Economics, 109-126.

Zungu, L. T., \& Grelying, L. (2021). Financial development and income inequality: a nonlinear econometric analysis of 21 African countries, 1994-2015. Retrieved from 